\title{
Introduction: Evidence for entheogen use in prehistory and world religions
}

\author{
MICHAEL WINKELMAN* \\ Retired, School of Human Evolution and Social Change, Arizona State University, Tempe, AZ, USA
}

(Received: July 7, 2019; accepted: August 11, 2019)

\begin{abstract}
This introduction to the special issue reviews research that supports the hypothesis that psychedelics, particularly psilocybin, were central features in the development of religion. The greater response of the human serotonergic system to psychedelics than is the case for chimpanzees' serotonergic receptors indicates that these substances were environmental factors that affected hominin evolution. These substances also contributed to the evolution of ritual capacities, shamanism, and the associated alterations of consciousness. The role of psilocybin mushrooms in the ancient evolution of human religions is attested to fungiform petroglyphs, rock artifacts, and mythologies from all major regions of the world. This prehistoric mycolatry persisted into the historic era in the major religious traditions of the world, which often left evidence of these practices in sculpture, art, and scriptures. This continuation of entheogenic practices in the historical world is addressed in the articles here. But even through new entheogenic combinations were introduced, complex societies generally removed entheogens from widespread consumption, restricted them in private and exclusive spiritual practices of the leaders, and often carried out repressive punishment of those who engaged in entheogenic practices.
\end{abstract}

Keywords: mushrooms, religion, shamanism, origins of religion, psychedelics, entheogens

\section{INTRODUCTION: PSYCHEDELIC USE IN HUMAN ANTIQUITY}

When human ancestors first intentionally ingested psychedelics will forever remain unknown, but what is certain is that millions of years ago hominins encountered psilocybincontaining mushroom species across the temperate regions of the world and undoubtedly consumed them. Just when our ancestors began to deliberately use these consciousaltering substances in rituals will never be known with certainty. However, we can be reasonably certain that more than a million years ago, our Homo habilis and Homo erectus ancestors and their mimetic capacity expressed in group song and dancing expanded beyond the nighttime displays characteristic of hominids (Donald, 1991; Dunbar, 2014; Winkelman, 2009, 2010a, 2010c, 2015) as they were extended by the effects of psychedelic mushrooms. This expanded visionary ritual capacity set the foundations for the emergence of shamanism and the deliberate use of psychoactive plants to enhance ritual activities and visionary experiences.

The evidence for the ancient ritual consumption of psychedelic plants and their influence on human evolution is partially substantiated by the converging evidence reviewed here:

1. Psilocybin-containing species are found virtually in all regions of the world and stretching back millions of years, as evidenced in psilocybin-containing species unique to each of the major regions of the world;

2 . the enhanced binding of the human serotonin receptors with psychedelics;
3. shamanic traditions of ritual use of sacred mushrooms and other psychedelic substances that have great antiquity, as attested to language, art, petroglyphs, and stone sculptures of fungiform figures that often closely resemble the observable features of local psilocybin-containing mushroom species; and

4. ancient psychedelic mushroom use attested to in artifacts from religious traditions in all of the major regions of the world.

\section{Worldwide psilocybin mushroom species}

The human engagement with psychedelics was inevitable in the form of psilocybin-containing mushrooms. The widespread presence of species containing psilocybin across most ecozones (Guzmán, 2005, 2009; Guzmán, Allen, \& Gartz, 1998; Stamets, 1996) indicates that they were widely present as environmental influences affecting hominin adaptations across the major inhabitable regions of the earth for millions of years. There is a worldwide distribution of psychedelic fungi, especially the psilocybin-containing species, as well as other fungi that are used as entheogens. Psychoactive fungi are found across most ecozones. In the Americas, they have been noted as far north as Alaska and as far south as Chile; other Southern Hemisphere extremities include Australia and New Zealand. The presence of psilocybin-containing species across the tropics and

\footnotetext{
* Corresponding address: Michael Winkelman; Caixa Postal 62, Pirenopolis, Go. 72980-000, Brazil; Phone: +1 623239 1662; E-mail: michaeljwinkelman@gmail.com
}

This is an open-access article distributed under the terms of the Creative Commons Attribution-NonCommercial 4.0 International License, which permits unrestricted use, distribution, and reproduction in any medium for non-commercial purposes, provided the original author and source are credited, a link to the CC License is provided, and changes - if any - are indicated. 
extending far into northern latitudes assured that our various ancestor species commonly encountered and ingested psilocybin-containing mushrooms.

The premodern worldwide distribution of psychedelic mushrooms is illustrated by regionally specific species. In addition to species unique to Thailand (Psilocybe samuiensis), New Zealand (Psilocybe aucklandii), Australia (Psilocybe australiana and Psilocybe subaeruginosa), Japan (Psilocybe argentipes and Psilocybe subcaerulipes), and Africa (Panaeolus africanus and Psilocybe natalensis), there are psychoactive fungi that are distributed across major regions of the earth such as the Northern Hemisphere, Eurasia, tropical and subtropical zones, and the Arctic and Alpine areas (Guzmán et al., 1998). This distribution, especially the numerous region-specific species that attest to their ancient presence, shows the inevitability of worldwide premodern exposure of hominins to psychedelic species.

\section{Psychedelic influences in hominin evolution}

The evidence for psychedelic influences in hominin antiquity is indirect, but undeniable with the weight of diverse forms of evidence. Humans have a long-term evolutionary relationship with psychotropic plant substances, a relationship that resulted from their selective effects on human evolution (Sullivan \& Hagen, 2002). There were a variety of ancient exposures to plant substances that effected human evolution, with our ancestors acquiring fitness benefits as a consequence of the use of psychoactive substances (Sullivan, Hagen, \& Hammerstein, 2008).

The use of psychedelics exemplifies these enhancements of neurotransmitter functions as a consequence of their ingestion in plant sources. Evidence for the influences of psychedelics on human evolution is found in the greater sensitivity of the binding of psychedelics with the human serotonergic system than is the case for chimpanzees (Pregenzer, Alberts, Bock, Slightom, \& Im, 1997). These differences reflect the survival advantages that resulted from their use and the consequent selection for those ancestors with an enhanced capacity to utilize these exogenous analogues of the serotonergic neurotransmitters, influencing a major neuromodulatory system. The human-chimpanzees differences in the sensitivity of response of the serotonergic system establish that there were ancient hominin adaptations involving selection for those ancestors in the hominin line that had a capacity for enhanced binding with psychedelics.

Hominin adaptations to the secondary metabolites of fungi, particularly distinguishing among toxic species, food sources, and consciousness-altering psychedelic species, were significant for human survival. Consequently, human ancestors underwent a multimillion year process of acquiring biological and eventually cultural adaptations to distinguish among mushroom species and their appropriate use. These experiences could have functioned as selective factors in the evolution of specific characteristics of the human brain, our neurotransmitter systems, and our innate psychology that could best exploit these serotonin- and dopamine-enhancing effects.
These psychoactive effects were inevitably incorporated into the central dynamics of shamanic rituals, attested to in the diverse species used as sacraments or entheogens in cultures around the world (see Rätsch, 2005; Schultes, Hofmann, \& Rätsch, 1992). Shamanism was central to premodern ritual practices, attested to in the worldwide presence of shamanism in foraging societies (Winkelman, 1992). This ritual activity was central to many aspects of human adaptation and evolution, including subsistence, social organization, healing, cosmology, and symbolic cognition (Winkelman, 2010a).

\section{Entheogens in shamanic origins}

Shamanism was central to premodern ritual practices worldwide, attested to the presence of remarkably similar shamanistic practices and beliefs in foraging societies crossculturally (Winkelman, 1992, 2010a, 2010b). The entheogenic contributions to the origins and evolution of shamanic practices are indicated by the substantial parallels between the basic principles of shamanism and the experiences induced by psilocybin mushrooms and other psychedelics. Ethnographic accounts reveal repetitive features associated with the ritual use of psychedelics in cultures around the world (Dobkin de Rios, 1984; Winkelman, 2007). These include the belief that they are:

- entheogenic, inducing an internal sense of spiritual presence;

- provide access to a spiritual world, the supernatural, bringing the world of mythic beliefs into experience;

- produce an experience of one's soul or spirit and its separation from the body and travel to the supernatural world;

- cause experiences of the activation of powers within and outside of the person;

- induce experiences of relationships with animals and at times the sense of transformation into an animal;

- provoke experiences of ego death followed by transformation or rebirth;

- provide information through visions;

- engage healing, especially through the dramatic ritual evocation of emotional experiences; and

- provide processes for group integration and enhanced social cohesion.

Guerra-Doce $(2006,2015)$ similarly notes that the predominant model of entheogenic consumption in foraging societies is associated with shamanic practices, where the shaman consumes the sacrament to enhance the healer's spiritual force and divinatory capacity for purposes of healing. These entheogenic practices generally occur in a communal ritual context with the attendance of the entire local group, who are often subjected to the conditions of ritual-fasting, as well as the experiences from drumming, singing, and clapping and overnight vigil. These ritual practices enhance the effects of the entheogen in producing experiences of communication with divinities for a range of objectives. These include: diagnoses of disease and guiding treatment; establishing contact with the ancestors to obtain advice; seeking advice from the spirits regarding plans for the future; acquiring information regarding hunting and 
about missing family members; and seeking to influence spiritual forces to enhance well-being.

The institutionalization of the effects of psilocybin within communal ritual practices was inevitable foundational influences in the evolution of human religiosity, as well as significant aspects of our evolved psychology (Winkelman, 2010a, 2013). Psychoactive substances were inevitably incorporated into the central dynamics of shamanic and religious rituals, attested to in the diverse species used as sacraments or entheogens in cultures around the world (see Dobkin de Rios, 1984; Rätsch, 2005; Schultes et al., 1992). Shamanism provided the cosmological and ritual context within which the experiences induced by psychedelics were incorporated into human culture, and through their selective effects, into humans' innate psychology (Winkelman, 2010a, 2013, 2014a, 2014b). These influences also contributed to the development of ritual healing practices, exploiting principles that were part of the formation of our evolved sociality and psychology (Winkelman, 2015). These shamanic activities played a key role in the evolution of hominins (Winkelman, 2010c) and the evolution of modern human cultural during the Middle/Upper Paleolithic some 50,000 years ago (Winkelman, 2002).

Rossano $(2007,2009,2011)$ points out that the interaction of shamanic ritual context with the evolution of the human brain contributed to selection for susceptibility to hypnotic and placebo effects. The well-known "suggestibility" and contextual effects (set and setting) produced by psychedelics indicate that their use would have also contributed to these tendencies to be influenced by the expectations of others. This selection occurred because of the health benefits provided by the mental states that enhanced susceptibility to ritual healing and the ability to use alternate identities, supernatural beliefs, and internalization of the expectations of others to produce beneficial internal states. This ritual context also selected for greater propensities for a variety of personal, interpersonal, and cognitive responses that enhanced ritual healing processes.

Psychedelics enhanced the survival and reproduction of those who could best exploit and benefit from their effects; consequently, psychedelics operated as environmental factors that selected for those who had greater degrees of those innate qualities that were elicited by the neurobehavioral effects of psychedelic and exploited by ritual processes. The selective effects of psychedelics exercised their influences in the context of enhanced capacities for participation in ritual and healing activities. These involved the enhanced cognitive states that were produced by the effects of psychedelics (enhanced serotonin and its effects of brain function; see Winkelman, 2014b, 2017b).

Humans have sought out not only psychedelic mushrooms for their consciousness altering properties, but a wide variety of plant substances as well. While a principal conceptualization of psychedelics is that they involve the ethnobotanical (and chemical) substances with action on the serotonin 5HT2 receptors (such as psilocybin, ergots, ayahuasca, and bufotenine), the visionary and entheogenic substances are not limited to this class of action. Visionary and entheogenic experiences are produced by diverse classes of plants and their respective neurochemicals and their effects on diverse neurotransmitter systems, not only serotonin, but also dopamine, endocannabinoids, GABA, muscarine, and others (see Winkelman, 2017a, 2017b for review). The human potential for entheogenic experiences and visionary encounters appears to reflect innate properties of our nervous system, a potential elicited by many different drug and non-drug mechanisms (also see Winkelman, 2011). This human search for drug-induced spiritual encounters has an intimate relationship with our evolved psychology (Winkelman, 2013, 2014a, 2014b) and has led humans to discover many different plant substances for altering consciousness.

\section{The antiquity of Homo sapiens' relationships with psychoactive plants}

In his paper here on "The oldest archaeological data evidencing the relationship of $H$. sapiens with psychoactive plants," Giorgio Samorini provides a worldwide overview of what we know about the prehistory of entheogenic practices. As modern instruments become increasingly sophisticated and sensitive, they are capable of detecting the presence of miniscule quantities of psychoactive plant sources in various archeological materials. These varied approaches (also see Fitzpatrick, 2018) are providing hard evidence of the antiquity of humanity's use of botanical agents known for their ability to induce alterations of consciousness. Samorini's review of the archeological literature on the presence of psychoactive plant sources shows evidence of $H$. sapiens' relationship with psychoactive plant sources going back nearly 10,000 years. This synthesis regarding the earliest knowledge of the main psychoactive plant sources of the world indicates the antiquity of use of diverse plants sources, but not always providing certain knowledge regarding their mode of use (i.e., intoxicant, food, or material).

A more pressing question for Samorini's findings is whether the use of these plant substances was for entheogenic purposes or for other reasons. In some sense, these questions might always remain ambiguous, but from the perspective of the entheogenic paradigm, the meaning of the facts is less ambiguous. If our distant ancestors deliberately left psychoactive substances in graves and other deposits, is there a fundamental ambiguity regarding what the message is here? The limited grave goods attest to the substantial significance that people placed in these objects, and more so, their implications for concepts of the spiritual and afterlife. Burials are intrinsically entheogenic in their intentions, an unequivocal statement that people perceived these substances as central to relationships with the spiritual and the afterlife. The presence of mushroom representations is particularly powerful evidence in this regard, attesting to a central concern with entheogenic experiences. There is no reason to presume that the fungiform representations were depictions of culinary activities or incidental environmental features. The inclusion of mushroom effigies in burial goods and ritual artifacts attests directly to their significance in the production of entheogenic experiences. Proposals of non-entheogenic purposes to ancient mushroom representations face the burden of proof and ought to be backed by evidence, not just offered as speculations. 
The diversity of psychoactive plant substances used in the past as indicated in Samorini's review here makes an important point. The widespread use of diverse plant substances and psychoactive ingredients to evoke common themes of entheogenic experience and shamanism reveals that what is important about these agents is not many different and specific forms of psychophysiological action, but rather the common shift in consciousness that is produced by many different psychoactive agents and mechanisms (Winkelman, 2011, 2017a). It is the general principle of the alteration of consciousness, which is relevant to understanding entheogenic experiences. While the specific substances used may not conform to the "classic psychedelic" - those acting at the 5HT-2 serotonin receptors the real issue is their visionary and entheogenic capacities, induced through a variety of pathways or mechanisms, but resulting in a common physiological condition of organismic operation (an integrative mode of consciousness; Winkelman, 2011).

As Fitzpatrick and Merlin (2018) point out, while humans' use of psychoactive substances falls into many different pharmaceutical categories (i.e., inebriants, stimulants, opiates, narcotics, hallucinogens, etc.), ethnographic analogies suggest that their use in the past generally shares a common entheogenic function of divine communication, even if the substances involved are not generally considered to be hallucinogenic or psychedelic (acting at 5HT2 serotonin receptors). The classification of the use of these diverse psychoactive substances as entheogenic in purpose is appropriate, given the typical perspectives of most cultures toward the use of varied classes of psychoactive substances that are employed to enhance experiences of contact with deities and supernatural forces. An entheogenic perspective may be valid even in the cases of substances with recognized alcohol content because of the widespread practice of mixing other psychoactive substances in the fermentation process to enhance the effects.

The integrative mode of consciousness emerges with the elevation of ancient brain functions by diverse process that promotes psychodynamic growth and cognitive, social, and psychological integration. Diverse ritual activities induce this integrative mode of consciousness, stimulating the autonomic nervous system through extensive ergotropic (sympathetic) activation until collapse into a trophotropic (parasympathetic) dominant state with a slowing of the brain waves into a more synchronized and coherent pattern (see Winkelman, 2011 for review). This extreme parasympathetic state is a recuperative state of the body, a state of extreme relaxation culminating in sleep and unconsciousness that restores homeostatic balance and evokes endogenous healing responses, especially through reduction of stress responses. This shift to parasympathetic dominance is also accompanied by a shift from left-hemisphere- to right-hemisphere-dominated brain processes and from frontal brain activity to predominant brain wave patterns emanating from lower brain structures. Winkelman (2017a, 2018) has reviewed evidence indicating that these diverse entheogenic substances result in the stimulation of innate modular structures and intelligences that provide the central features of spirit encounters.
The human search for chemically enhanced consciousness as a better conduit to experience divinity is a virtual universal of human cultures. And as will be illustrated in a number of articles below, this development likely began with the most easily available sources - psychedelic mushrooms - which were later supplanted by more complex combinations of plants. This primordial use of mushrooms as entheogens is illustrated by findings of fungiform artifacts from all of the major areas of the world, as seen in the following section of this introduction. While far from exhaustive, it establishes that there existed ancient spiritual practices in all of the major regions of the world that were entheomycological, finding entheogenic inspiration in locally available psychedelic fungi.

\section{MUSHROOM AND ENTHEOGENIC CULTS OF THE PAST}

By their nature, mushrooms are hard to detect in the archeological record, as their fleshy substance largely composed of water quickly deteriorates and leaves little if any physical trace. Consequently, the evidence regarding the roles of psychedelic mushrooms in cultural activities of the past involves fungiform representations in petroglyphs, rock art, sculptures, and metal artifacts found in cultures around the world. Samorini (2012) reviewed a wide range of mushroom forms found in cultures around the world, showing that mycolatry is a widespread ancient practice. Psychedelic mushrooms were encountered in most of the habitable regions of the world and displayed in ways that indicate that they were central features of early ritual systems. Their significance led their practitioners to capture the source of their experiences and their significance by producing images on stone.

\section{Asia}

A deep prehistory of mycolatry in Asia is well attested to in the presence of practices and mythology regarding Amanita muscaria and Psilocybe species (Figures 1 and 2) among diverse cultures of the region. Furthermore, there is reason

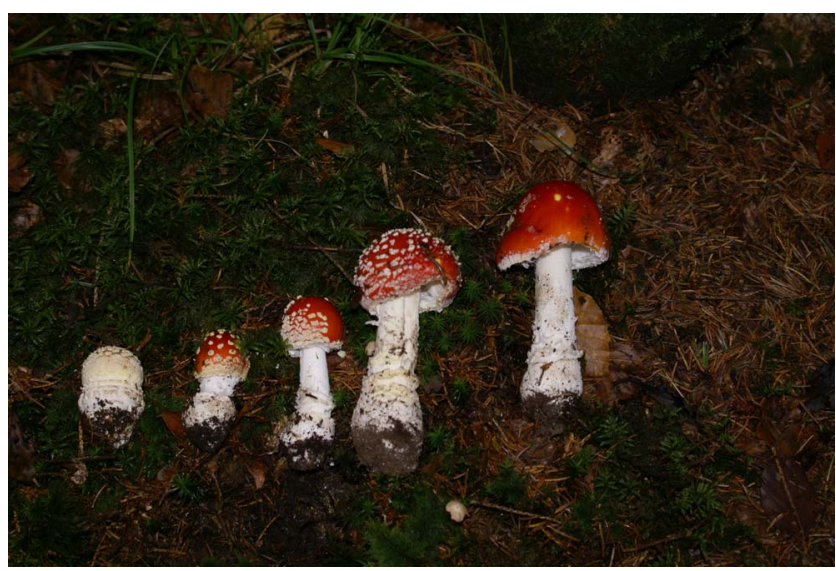

Figure 1. Amanita muscaria (photo credit: Meena Maillart; used with permission) 

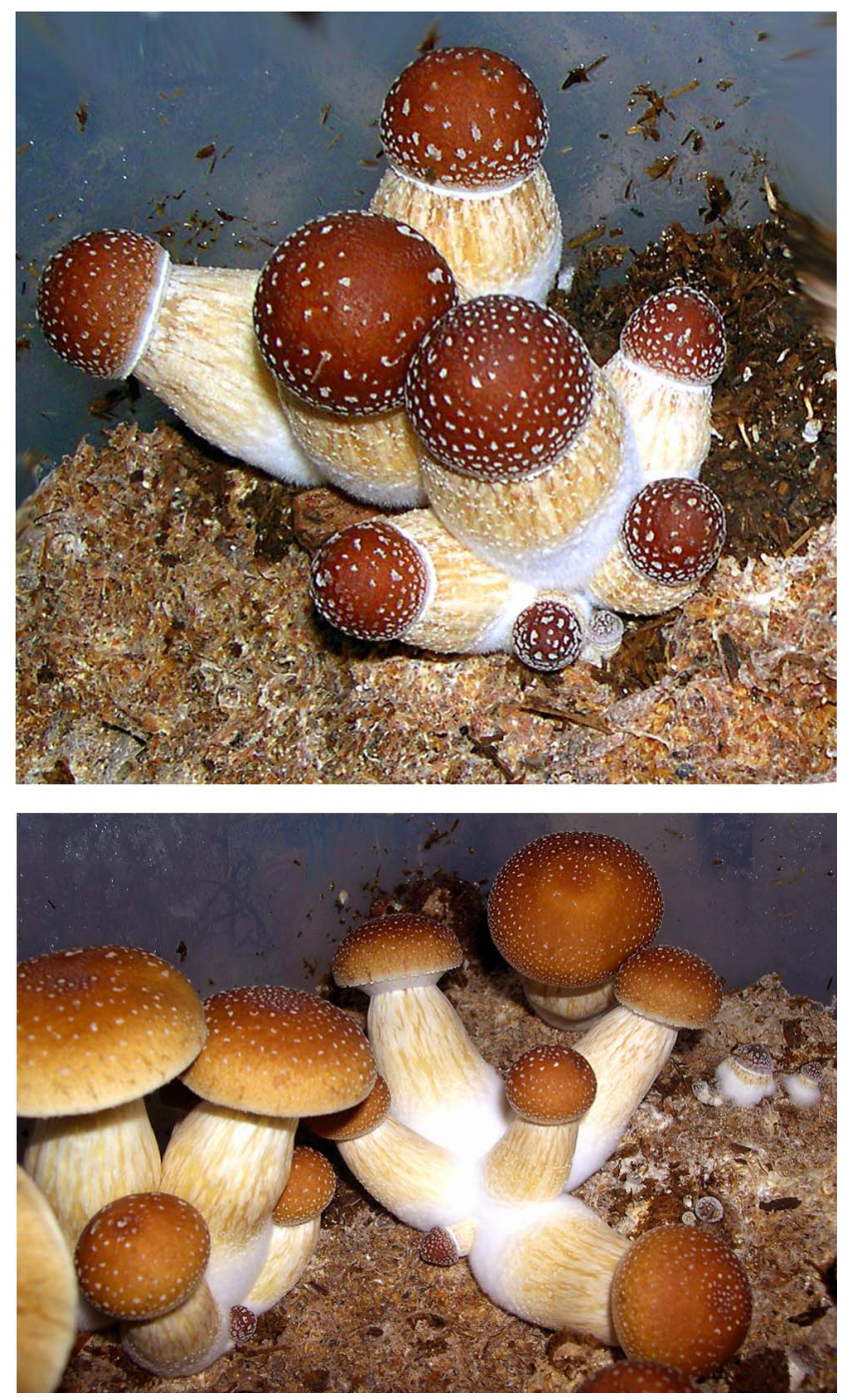

Figure 2. (a, b) Psilocybe cubensis grown from spores obtained in India (photo credit: John Allen; used with permission)

to expect that encounters with $A$. muscaria stretch back as long as hominins occupied the temperate forest regions of the Northern Hemisphere where these mushrooms grow in symbiosis with Betula spp. (birch) and Pinus spp. (pine trees).

\section{Prehistoric evidence}

The direct evidence for prehistoric mycolatry is found in a variety of mushroom and mushroom-human depictions found in the northern regions of Eurasia (see Hoppál, 2013; Rozwadowski \& Kosko, 2002). Panels in the Pegtymel River region of Siberia are exhibited on large rock formations. Figure 3 presents sketches of rock art images in the Sayan Canyon of the Yenisei from Devlet and Devlet (2002); they proposed that these portray human figures with mushroom-like heads and are reflections of ancient cults involving $A$. muscaria. The identification of $A$. muscaria, as opposed to other psychedelic mushroom species, is based on features exhibited on the headgear of the anthropomorphic being. Some of these mushroomshaped caps have shallow areas that appear to represent the white spots that are found on the caps of A. muscaria.
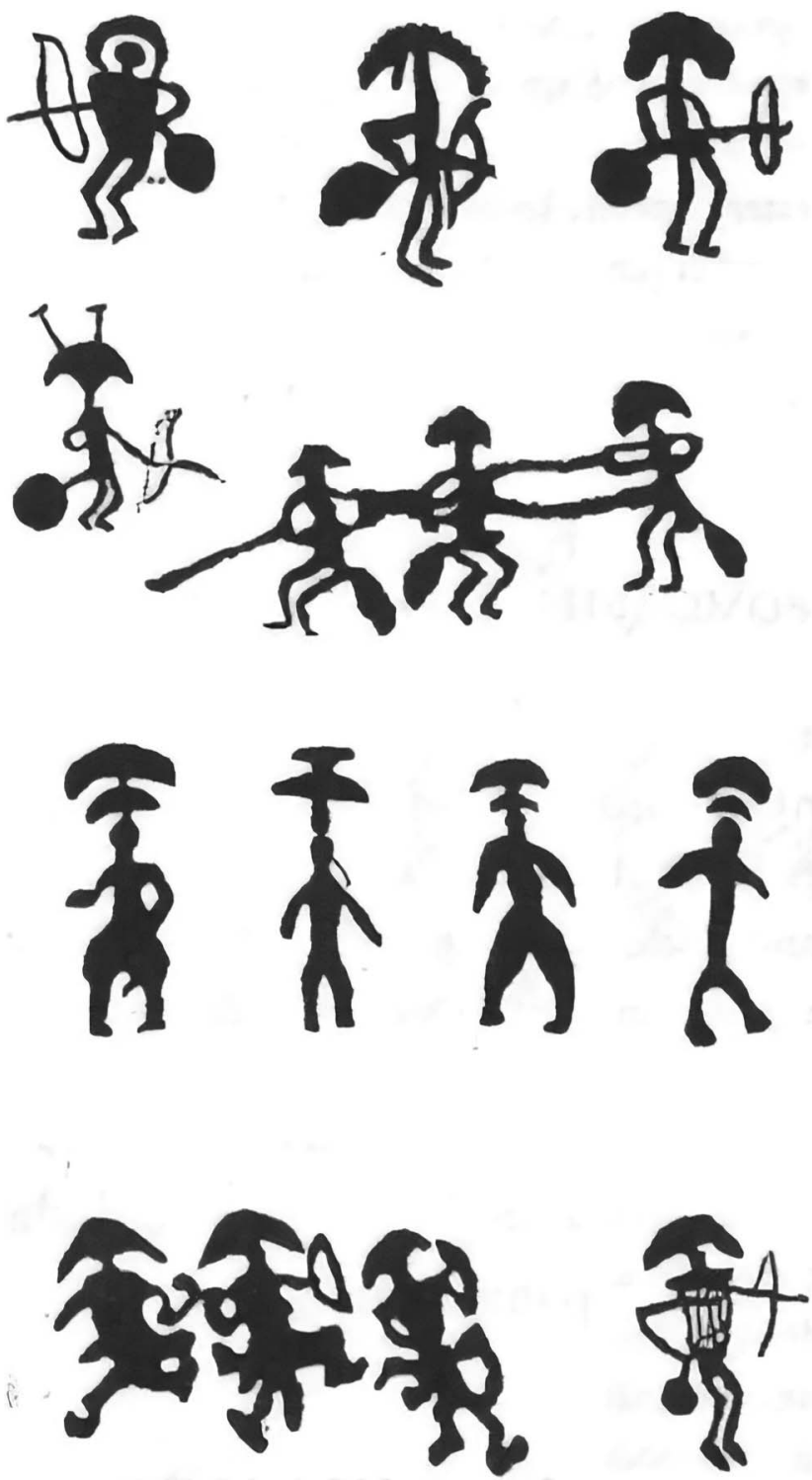

Figure 3. Representations of petroglyphs that Devlet and Devlet (2002) call "fly-agaric creatures" (in reference to A. muscaria) and discuss as shamanistic figures. Images found in Upper Yensi Basin, Khara-Chulun Mongolia, and the Pegtymel rick art site. Images used with permission of Andrzej Rozwadowski from Rozwadowski and Kosko (2002)

Guzmán (2016) has noted that some of these depictions may more closely represent Boletus species, which are used for their psychedelic effects in Papúa New Guinea (Reay, 1960) and China (Stijve, 1997). These petroglyph images of humans covered with giant mushroom shapes were likely made by the ancestors of the local cultures because the Chukchi mythology refers to human-like mushrooms and had practices of using $A$. muscaria that continued until the current era (Saar, 1991; Schurr, 1995).

Ethnohistorical studies show that the ingestion of $A$. muscaria was involved in shamanic practices, although there are more modern cases of non-ritual individual use. Bogoraz (1909) reported that the shamans among such diverse groups as the Yukagir, Kamchadal, Inuit, and Koryak and Chukchi ate the mushrooms and even drank the urine of reindeer intoxicated on the fungi, receiving an 
even more potent dose of the psychoactive ingredients once the more toxic substances were processed by the body (see Feeney, 2010; Schurr, 1995). This shamanic context of $A$. muscaria use was part of other ritual practices to produce alterations of consciousness experienced as a travel to and entry within the spirit world. The widespread association of the $A$. muscaria with reindeer reflects the animals' practice of consuming the mushrooms, as well as drinking the enhanced psychoactive substances in the drugged deer's urine. These behaviors may reflect the origins of human knowledge regarding the mushroom's intoxicating properties still present in the urine.

\section{The Soma controversy}

In their article "The 'Kamasutra' Temples of India - a Case for the Encoding of Psychedelically-induced Spirituality," Meena Maillart-Garg and Michael Winkelman address one of the most famous entheogenic controversies, the identity of Soma of Hindu traditions, proposed to be the mushroom A. muscaria by Wasson (1972). The presence of mushroom representations in the sculptures of sanctuaries of the Khajuraho Temples provides evidence that entheogenic mushrooms are the identity of soma. They analyze the features of these fungiforms and Vedic traditions to propose that these are designed to depict both the A. muscaria, as well as Psilocybe cubensis species (see Figures 1 and 2a,b). They further propose that some of the so-called "broken" sculptures of Khajuraho are not actually damaged, but rather deliberately constructed to appear vandalized to encode information related to entheogens in the "figure 8" form of the early stage of $A$. muscaria. The central placement of mushroom pedestals as necessary steps into the sanctum of the temples attests to a profound entheogenic message. This physical and symbolic data has considerable implications for a reevaluation of the ancient roots of Hinduism, indicating that entheogenic mushrooms were the most important sacraments of early Hinduism and persisted for millennia.

\section{Entheogenic mushroom use in complex Asian societies}

Wasson's (1972) proposal of the existence of a widespread entheogenic $A$. muscaria mushroom tradition across Eurasia has various forms of support from findings reported for complex societies as well. The continuation of mushroom cults in complex societies of Asia was illustrated by Crowley (2015), Dannaway (2009) and Hajicek-Dobberstein (1995), who review evidence of religious mushroom cults. Psychedelic mushroom use is reported for Taoist cult practices documented in Tibet and China by Crowley (2015) and Hajicek-Dobberstein (1995), as well as across the ancient Indo-Aryan world from India to Greece (Ruck, Staples, \& Heinrich, 2001). Chinese traditions recorded the use of hallucinogenic plants, including mushrooms, in herbal manuscripts almost 2,000 years ago. Dannaway (2009) points to evidence the use of botanicals substances as tools for obtaining siddhis or mystical powers in: the yogic tradition of Patanjali; ancient Buddhists texts, especially in the Buddhist Tantric traditions; and Taoist literature, the later making references to what is translated as "magic mushrooms" and "divine mushrooms."
Hajicek-Dobberstein (1995) reviews biographical accounts of some legendary Buddhist adepts from the first millennium (200-900 AD) that provides clues to a psychedelic practice represented in symbols that suggest that they consumed A. muscaria as a tool for achieving enlightenment. The identity as $A$. muscaria is revealed in common symbols representing Soma in the $\mathrm{Rg}$ Veda, Buddhist traditions, and ancient shamanic practices found across Northern Eurasia. Hajicek-Dobberstein (1995) presents evidence that "The congruity of the set of symbols in the legend of Arydeva and the sets of symbols in the mythology of A. muscaria from Siberian and Vedic traditions is too strong to be a coincidence" (p. 109). For instance, the Sanskrit term "madhu," meaning "'honey, sweetness, delicious," is a common description of Soma in the Rg Veda; such descriptions parallel the characterizations of the Buddhist Amrta as a "nectar of the gods," a delicious food and drink. The exalted and sacred status attributed to the birch tree in Siberian and Altaic cosmology and its central roles in shamanic rites reflects the trees' role as the habitat A. muscaria, constituting the preferred mycorrhizal symbiont of the species. Hajicek-Dobberstein (1995) proposes this is the reason for the significance of the birch as a "great drug" in India pharmacopeia in spite of its rather innocuous medicinal properties, a reflection of its status derived from its role as the symbiont of $A$. muscaria. Paralleling the Siberian mythologies of one-eyed demons, Vedic texts describe beings with a single eye associated with Soma that Wasson interpreted as derived from the characteristics of the early stage of development $A$. muscaria when it appears similar to a bloody human eye-ball.

Hajicek-Dobberstein (1995) reviews materials from The Stories of the Eighty-Four Siddhas, representing later codifications of oral biographical legends that described experiences of notable Buddhist adepts using psychedelic mushrooms. These stories indirectly convey such experiences in words and symbols that embed a deeper level of meaning in sandhabhasa, an "enigmatic language" that simultaneously reveals a secret message to the initiates while openly obscuring the true facts for the uninitiated. But as is the case in other traditions, the Buddhists texts provide the identity of $A$. muscaria for this elixir of enlightenment in its features as a magically potent urine, the one-eyed and one-legged beings, and the references to its symbiont birch tree.

Crowley (2015) explores further psychedelic associations with a class of Buddhist deities with the name Ușnīṣa, referring to the crown of the head, specifically a "crownbump" (umbo) or cranial protrusion that characterized them, as well as the depictions of many Buddhas. Crowley presents evidence that these crown bumps represented a tantric Buddhist sacrament derived from earlier traditions of psychedelic mushroom use. Based on analysis of liturgical data in the Sadhanamala and the traditions associated with the sacramental amrita, Crowley contends that these bumps are representations of Psilocybe species.

Crowley notes that the lack of an explicit Sanskrit term for mushroom led to the use of terms such as "umbrella" and "parasol" (along with other terms such as silindhraka, meaning "maggoty thing") to refer to mushrooms. Silindhraka also has the meaning of "growing on cow dung," 
a reference to the proclivity of $P$. cubensis and other psilocybin-containing species to grow up through bovine dung. Various references to the blue neck and staff of the parasol reflect the dark ring hanging on the mushroom's stem that is characteristic of $P$. cubensis; and the tendency of the flesh to bruise blue that is characteristic of psilocincontaining species. Crowley extends his analyses to Japanese Buddhist traditions where representations of various deities include depictions of mushrooms that resemble various entheogenic species of the Psilocybe genus characteristic of the region $(P$. liniformans and $P$. argentipes). Further analyses of the meanings of the names of the various Ușnīsas provide confirmation of his interpretation of entheogenic mushrooms in features that reflect the physical features of the mushrooms (sprouting, specific colors, wheel-like, etc.), their growing seasons (rainy), and effects (quick acting and vomiting).

\section{Soma as ayahuasca analogue}

In the article on "Soma and Haoma: Ayahuasca analogues from the Late Bronze Age," Matthew Clark continues the examination of the various identities of the entheogenic soma, noting the common elements in the myths and religious practices of both Indian and the Zoroastrianism practices of Persia. Clark notes that the sacred texts have references to several different kinds of soma/haoma and examines the consistency in the evidence for various botanical candidates proposed for Soma. He proposes that this "nectar of immortality" was eventually derived from complex plant formulas that included more than a dozen plants. These included DMT sources and monoamine oxidase inhibitors, as well as other psychedelic substances that provided a synergistic formula similar to the famous ayahuasca from South America. He proposes that knowledge of psychoactive properties of the constituent plants was widely diffused from their origins in Central Asia to India and then Persia.

Many plant identities proposed for soma suggest that there were likely more than a single soma. The widespread Eurasian shamanistic use of A. muscaria indicates that it must be considered as a primordial entheogen of the region. During cultural development, a variety of factors made $A$. muscaria less available (i.e., deforestation of the symbiotic trees) and the entheogen was replaced by other substances then more readily available (coprophilous or fimicolous Psilocybe species), and eventually more complex botanical and chemical combinations that served the same purpose in altering consciousness.

\section{Africa and the Middle East}

There is limited ethnomycological data for the ancient use of psychedelic mushrooms of Africa. There are, however, widespread contemporary traditions of hallucinogen use (see De Smet, 1996; Sobiecki, 2017). Some of the most significant entheomycological data is the evidence from the well-known petroglyphs in the Tassili caves in the south of Algeria (Lajoux, 1964; Lhote, 1968; Mori, 1974, cited in Samorini, 1992). Mycological traditions are also suggested for Ancient Egypt, where fungiform representations in
Egyptian crowns provide iconic symbols of entheogenic traditions (Berlant, 2005).

Samorini (1989, 1990, 1992) characterized the Tassili petroglyphs and rock paintings as possibly the most ancient of the physical evidence for ethno-mycological practices, hypothesized to date 7000-9000 years BP. Echoing previous analyses, he proposed that these works of art reflect the states of consciousness produced by psychedelic mushrooms and the associated ritual dances that are clearly reflected in the postures of some of the figures. Based on their features, Guzmán (2012) proposed these mushroom figures represent Psilocybe mairei, but they also resemble other African psychedelic species, including P. cubensis and other species known in the region (Psilocybe aquamarina and $P$. natalensis; Guzmán, 2016).

The shamanic nature of the associated ceremonies was noted by the discoverer of this Tassili art, Henri Lhote (1968, 1973), who pointed out that these remote painted cave walls served as secret sanctuaries, consistent with specialized ritual activities. In one panel there are several figures shown in active postures implying dancing, with each holding a mushroom-shaped object (see Figure 4). Samorini (1992, p. 6) notes: "two parallel lines come out of this object to reach the central part of the head of the dancer, the area of the roots of the two horns. This double line could signify an indirect association or nonmaterial fluid passing from the object held in the right hand and the mind. This interpretation would coincide with the mushroom interpretation if we bear in mind the universal mental value induced by hallucinogenic mushrooms - the lines an ideogram which represents something non-material in ancient art-represent the effect that the mushroom has on the human mind." Shamanic figures with mushroom features are repeated in other petroglyphs of the region; see Figures 5 and 6), with a typical gait of a dancing figure with legs bent inward and with the depiction of mushroom figures in the hand as well as on the forearms and thighs and distributed in the area around the body.

These are not the only mushroom depictions in African cultures. Mushroom-head figures adorn the front cover of the 1993 South Africa Archaeological Bulletin (vol. 68 \#57; also see Hollmann, 1993), depicting scenes from the Bella Vista site in Ladybrand District of the Orange Free State.

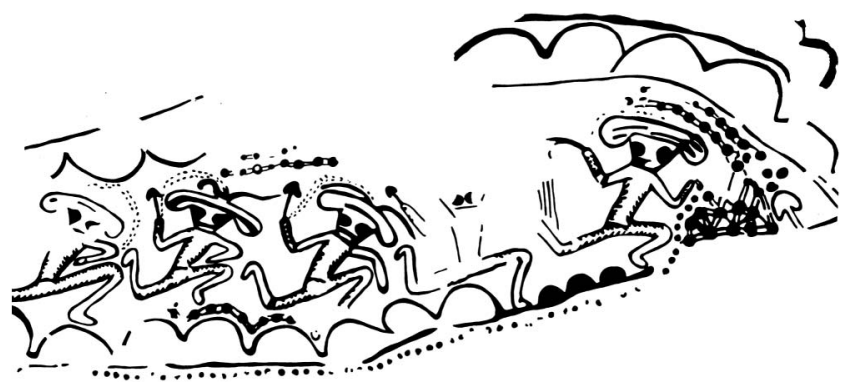

Figure 4. Relief of a painting in a rockshelter of Tin TazariJt, Tassili, Algeria that Samorini interprets as dancing figures with a mushroom as a head and a mushroom-like object in the right hand with lines coming out of this object and extending to the head of the dancer, representing some energy passing from the object to the mind (photo credit: Giorgio Samorini; used with permission) 


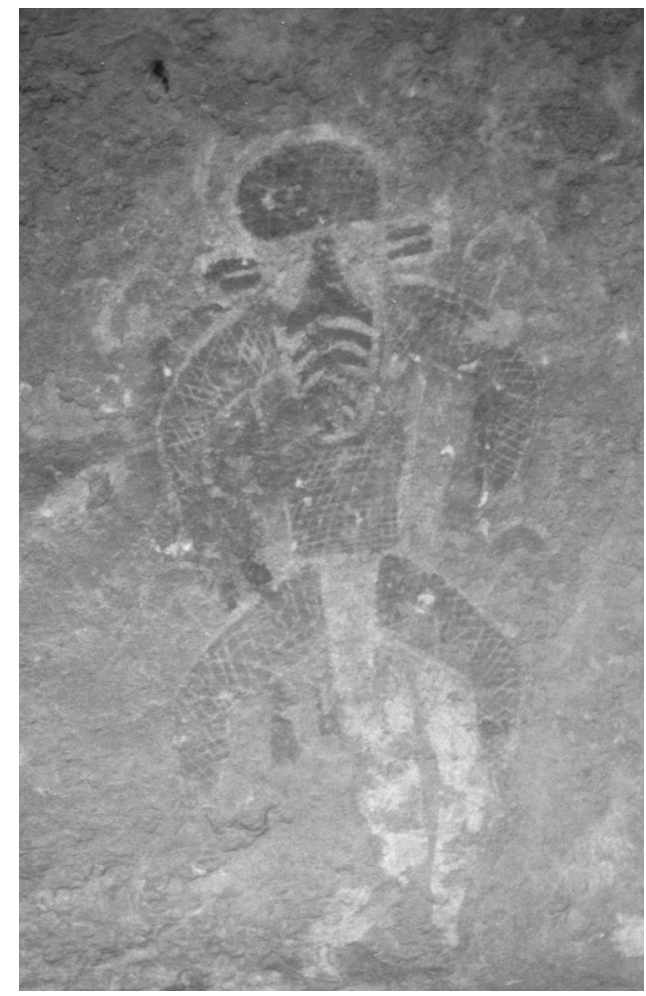

Figure 5. Photograph of a petroglyph that Samorini calls a "Mushroom Divinity" located at In-Aouanrhat, Tassili (Algeria) (photo credit: Giorgio Samorini; used with permission)

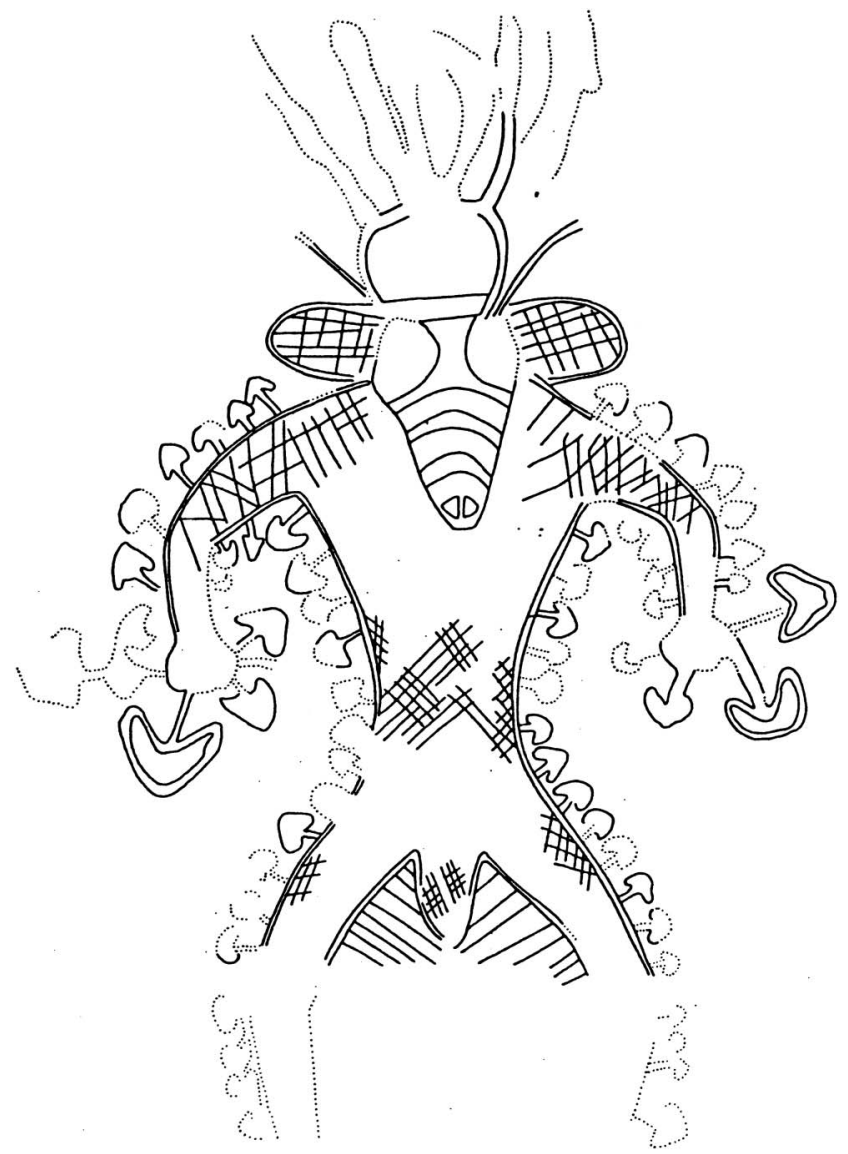

Figure 6. A sketch of the petroglyph at Ti-n-Tarin, Tassili (Algeria) that Samorini calls a "Mushroom Divinity" (photo credit: Giorgio Samorini; used with permission)
These images portray a group of men dancing in the style of the San shamanic medicine dance. These figures are mostly characterized by various mushroom shapes on their heads, and in a few cases, with inverted mushroom caps with birds (a classic symbol of shamanic flight), which are shown within the mushroom cup on top of the body (in place of a head). The association of the mushrooms with the medicine dance reinforces the shamanic interpretation and functions of the mushroom caps, a primordial iconic symbol of the locus of effects of the entheogens.

\section{Old Testament evidence for entheogens}

The article "Getting High with the Most High: Entheogens in the Old Testament" by Danny Nemu presents evidence of the use of entheogenic substances in ancient Judaic traditions. Nemu compiles evidence from scripture, historical sources, and archeology to identify the plants likely found in the Old Testament Manna, Showbread, the Holy Ointment, and the Tabernacle Incense. The psychoactive significance of the ointment and the incense is in their proclaimed role enabling the priestly caste to have a direct experience of their God. The sacramental way they are consumed and the taboos around them are highly suggestive of their use as psychoactive agents. Furthermore, the psychoactive components found in these preparations include GABA receptor agonists and modulators and opioid receptor agonists, as well as enzyme inhibitors that permit them to be orally active. The combinations in these preparations show that the ancient Israelites understood the plant synergisms involved in producing entheogenic experiences and deliberately employed them.

Ruck et al. (2001) provide further evidence for $A$. muscaria practices in Judaic traditions, characterizing Moses as an entheogenic shaman, especially in his encounters with the "burning bush" on the "Mountain of God." This bush, with a flaming center that did not burn or consume the bush, also spoke to Moses, giving him instructions. Ruck et al. (2001, p. 164) point to the features of $A$. muscaria in burning coal and white ash appearance of the tree, as well as in the signs given by Yahweh to Moses to convince the followers - his hand showing "leprous patches white as snow" (resembling the A. muscaria veil remnants on the cap) and the ability to take his hand from his cloak and "to draw water and have it turn red" - (the liquid pressed out of the mushroom). Other circumstantial evidence they present includes the coincidence of the season for obtaining these mushrooms and grazing sheep in the mountains - after the rains. Signs of $A$. muscaria effects are also found in Moses' symptoms of violent illness and his subsequent "superhuman courage and confidence."

\section{Islamic entheogenic roots}

In his article "Burāq depicted as $A$. muscaria in a Fifteenth Century Timurid Illuminated Manuscript?," Alan Piper present evidence of enthogenic roots within Islamic traditions derived from Turkey and Afghanistan. These influences are expressed in the Herat manuscript, which provides descriptions of the formative experiences of the Prophet Mohammed. These include the mi'raj - the miraculous 
accent of the Prophet Mohammed through the seven heavens to receive God's instructions - and the proceeding isra - the "Night Journey" - during which Mohammed traveled overnight from Mecca to Jerusalem by means of a fabulous beast called Burāq. Piper analyzes the illustrations of this manuscript, reflecting Islamic traditions formed in an admixture of Turco-Mongolian shamanism, which records Mohammed's mi'raj. Piper shows that descriptions in the Herat manuscript that depict the fabulous creature through which Mohammed makes this ascent share distinctive features of the A. muscaria, depicting the Burāq with the distinctive red and white spotted skin of the mushroom. Piper makes an argument for shamanic and entheogenic interpretations based on several elements, including the similarity between the mi'raj and shamanic journeying. Mi'raj refers to a "ladder" that reaches from earth to heaven for the ascent and descent of the Angels of God, corresponding to the notched tent pole that Siberian shamans use as the axis mundi for their celestial ascents to the spirit powers. Features of Siberian shamanic spirit journeys and $A$. muscaria experiences are found in key elements of the mi'raj story. Piper uses ethnographic analogy for interpretation of this depiction of the Burāq through an interdisciplinary approach that shows how these representations of the Burāq depicted in the Herat manuscript are related to Islamic traditions influenced by Buddhism, Hinduism, and other regional cultures. An Islamic spiritual leader called Baraq Baba who is involved in a situation of consumption of vomit has analogies in the consumption of A. muscaria in Siberian cultures, a connection that may explain other parallels between the Burāq and A. muscaria.

\section{Europe}

Shamanistic practices using A. muscaria existed across ancient Europe (Rätsch, 2005), but these entheogenic rituals were generally lost, repressed, or hidden in esoteric cults long before the emergence of Christianity and the formation of modern Europe, making the evidence of their importance easy to overlook. Nonetheless, evidence for ritual practices using mushrooms are attested to numerous artifacts, especially in folklore, mythology, and early mystery religions of the region. These involved both Amanita and Psilocybe species, as well as other plant combinations.

\section{Fungiform representations of ancient Europe}

The oldest reported mushroom petroglyphs of Europe yet discovered are those found in the Selva Pascuala mural of rock art at Villar del Humo, a post-Paleolithic rock art site in Cuenca, Spain. Akers, Ruiz, Piper, and Ruck (2011) present evidence that these figures reflect the ritual use of Psilocybe in Europe as long as $8000 \mathrm{BP}$. The representations present fungiform figures that depict both the key features of Psilocybe hispanica-specific aspects of variation within the species, such as the straight to sinuous stalks, and convex to bluntly subconical caps that characterize the typical morphological variation observed in this species.

The shamanic interpretation of these fungal representations is substantiated by several additional facts. One is their depiction on a panel with a bull, a highly significant association given the proclivity for many Psilocybe species to grow in the dung of bovines. The shamanic interpretation of these depictions at Selva Pascuala is also supported by the austere location of this rock art, which was not a habitation site, but because of its isolation, suggests that it served a special ritual purpose.

Although these Psilocybe traditions, like those of $A$. muscaria, were largely lost in European antiquity, they are attested to the artifacts, mythology, and folklore of the cultures of region. The fungiform heads on petroglyphs in the western regions of Europe (Molodin \& Cheremisin, 1999) indicate such activities were still carried out during the Bronze Age, when such practices were apparently still widespread. Kaplan (1975) analyzed Bronze Age metallurgy and petroglyphs of Scandinavia to argue that the fungiform metal works are in fact representation of mushrooms used for ritual purposes. These mushrooms constituted symbols of a religious tradition of ancient ritual consumption of psychedelic mushrooms. However, many of these representations are highly stylized and leave unanswered questions regarding the ritual context of their use.

\section{Greek entheogenic roots}

There was a continuation of many earlier cults of $A$. muscaria within Greek culture, including Dionysus (Ruck, 2014). Their origins lie further in the past, derived from ancient Egyptian religions that were conveyed throughout Western Eurasia and northern Africa by a Hellenic inspired diffusion of the mysteries of Isis and Osiris throughout the Roman European empire (Ruck et al., 2001). Wasson, Hoffman, and Ruck (1978) identified A. muscaria as the sacramental offering to Apollo, an ancient entheogen of Greek culture that was later substituted with other psychoactive substances. Although $A$. muscaria was also associated with the Goddesses Demeter and Persephone of the Eleusinian mysteries, the identity of this ancient sacrament of the Greek mystery schools proposed by Wasson et al. (1978) in The Road to Eleusis was the LSD-like fungus ergot that grows on rye. The use of $A$. muscaria within the rituals of Dionysius and Apollo was secret and they were publicly portrayed as dangerous or ancient pagan practices to facilitate their cover-up. Even the manifestations in the ancient Greek-Roman world were subjected to official condemnation, imprisonment, and even death to those who practiced these entheogenic rites (Ruck, 2014).

A Classical Greek marble fragment (5th century BC; see Figure 7) is called "The Exaltation of the Flower," based on a mis-identification of the fungiform that is the central element between the heads of two females identified as the Demeter and Kore, also known as Persephone (Ruck, 2006; Samorini, 1998). The stella was found beneath the ruins of a Catholic monastery in Thessaly, Greece, which had been built on top of the shrine to Demeter. While various identities (i.e., opium poppy and flower) have been proposed for the fungiforms on the stella, the mushroom is the most direct resemblance, and certainly the obvious candidate given the nature of the location - a sacred site.

Ruck et al. (2001) illustrate the Greek entheogenic past as revealed in the many entheogenic features of the Greek hero 


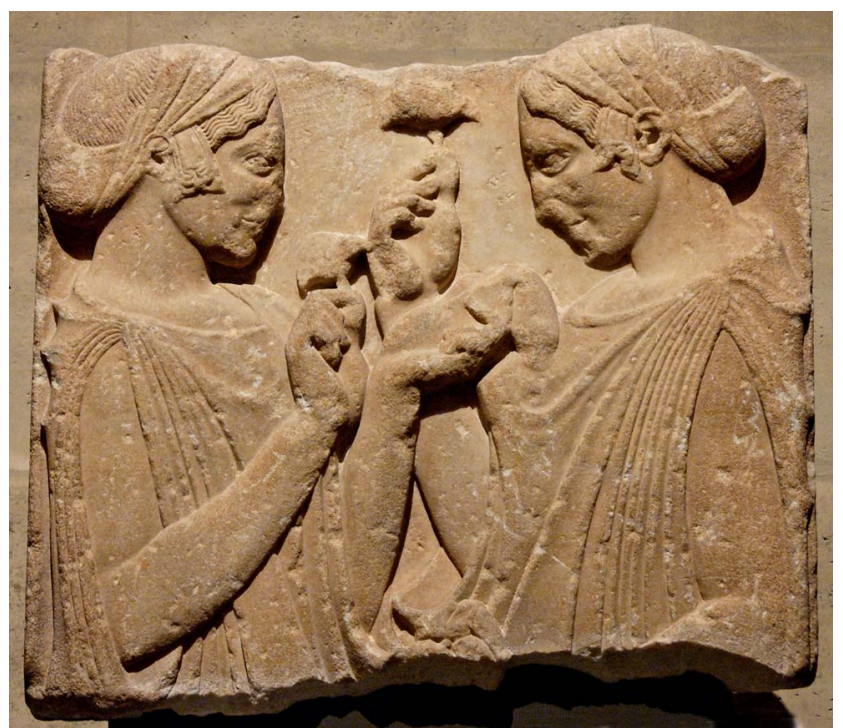

Figure 7. Exaltation of the flower (photo by Lan Nguyen placed in the public domain)

Perseus, known as the "mushroom picker," as well as associated mythological figures who have central features that provide symbolic representations of the physical features of $A$. muscaria. Physical characteristics and ecological and mythological aspects of $A$. muscaria use are suggested by the characterizations of deities and sacraments that have central features of the fungi, including: the reddish-orange and white color patterns; the associations with thunderbolts, rain, and bulls; the trees with which the mushroom grows in symbiosis; and the golden-red liquid extracted; as well as the subsequent use of the urine as the sacrament, among others.

Perseus is linked to another figure of Greek mythology, Jason, known for his exploits of acquiring the Golden Fleece and the Golden Apples, which have features directly associated with the characteristics of Amanita species. These include Jason's shamanic training, his identity as singlefooted, and the meaning of his name (Iason), which (Ruck et al., 2001) propose as "drug man." The association of the origins of Perseus (also known as Iamos) with a period of transition from matrilineal Greek culture to the patrilineal Olympian traditions speaks to a key social transition involving the use - and eventual abandonment - of the psychedelic mushrooms, which were seen as a challenge to the Olympian order.

\section{Women's roles in entheogenic traditions}

There are deep roots to European female entheogenic traditions, tied to the ancient regime of matriarchy and Aphrodite (Ruck, 2014; Ruck et al., 2001). These traditions of priestess and sorceresses involved knowledge of plant use that was also found among the traditions of the European midwives and female herbalists, who used a variety of methods to alter consciousness and heal. The activities of Greco-Roman priestesses of the various mystery religions provide ample evidence of the use of sophisticated pharmacological combinations that permitted the induction of a variety of ecstatic alterations of consciousness (Hillman, 2014;
Ruck, 2014). The association of aphrodisiacs with these entheogenic combinations attest to a period in which women themselves, rather than a male hierarchy, controlled their bodies and sexuality. These traditions were the context of the healing practices of Jesus, who famously exorcised the seven demons of Mary Magdalene, whose knowledge of herbal practices identifies her as a priestess of these ancient mystery cults.

These female-based entheogenic practices contributed to the formation of European and Christian practices through the traditions of Mithraism from the Zoroastrian practices of Persia (Hoffman, Ruck, \& Staples, 2002). They propose that the Mithraic practices involved the further evolution of these earlier mushroom cults from an ancient Indo-European culture that preceded the separate Hindu and Iranian developments, and constituting the original pan-Eurasian religion. The few descriptions of the Mithraic sacrament allude not only to its mushroom-like qualities (thrusting out of the earth, single-footed), as well as specific $A$. muscaria features (red caps, white jewels, associations with mountains, and the symbiotic tree species).

Ruck et al. (2001; Ruck, Hoffman, \& González-Celdrán, 2014) propose the Mithraic links as evidence of $A$. muscaria as the Christian Eucharist, arguing for a foundational role of A. muscaria in Christians' sacramental body and blood of Christ that are to be eaten and drunk, constituting a real rather than merely symbolic representation of that sacramental flesh and blood. The A. muscaria is a "flesh that contains blood" - a reference to the red liquid squeezed from the mushroom flesh when rehydrated. The stem is also a flesh, which with drying, turns a color similar to bread. Other parallels with the Eucharist include its production of a sense of vitality to life and a sense of unity with deity. Ruck et al. (2001) extend this analysis to the chalice of the Holy Grail, pointing out that the fully form $A$. muscaria presents as a chalice with its upturned edges forming a cup around the blood red cap.

The incorporation of the entheogenic practices of Mithras into the foundations of Christianity was facilitated by the widespread diffusion of the practices through the Roman Empire, where Mithraic rites were important mechanisms for the foundation of bonds of brotherhood among the soldiers of the Roman army and its political apparatus (Hoffman et al., 2002). While the later ascendant Catholic Church viciously persecuted the Mithraic religion, their entheogenic rituals persisted in pagan practices, as well as sects functioning secretly within the Church.

The entheogenic traditions of Europe retreated from public life and the male dominated priesthoods, which had antipathy for the shamanic alterations of consciousness. The last thing that the bishop wants to hear is that there is a new saint in the parish. This patriarchal rejection of the entheogenic traditions left them in the hands of women and their spiritual healing traditions. These ancient mushroom practices also persisted in the popular culture as attested to the survival of this information in diverse areas, such as its widespread association with toads and elves (Morgan, 1995). A. muscaria survivals include its highly probable role in historical and contemporary Christmas designs. Parallels with Siberian practices and beliefs suggest that symbolic remnants of these ancient $A$. muscaria traditions 
are still present in contemporary culture, reflected in representations of the red and white of Santa Claus, his flying reindeer, the associated birch and pine trees, and their hanging colorful gifts derived from practices of hanging the mushrooms to dry on these symbiont trees.

\section{Religious use of A. muscaria in Christianity}

There is a growing body of literary material recently reinterpreted in light of the entheogenic perspectives that present evidence for widespread entheogenic mushrooms cults across Europe, and even in the formation of Christianity. Evidence for the continuation of shamanistic A. muscaria practices in ancient Europe is found in a wide range of mythological and religious phenomena and artifacts (Ratsch, 2005).

The possibility of a broader European role of $A$. muscaria practices beyond its shamanic roots was boldly proposed by Allegro (1970), who in his book, The Sacred Mushroom and the Cross, attributed the origins of Christianity to an $A$. muscaria cult. The sacramental body of Christ is the mushroom, with the extracted red juice the blood that is also the sacrament. Allegro presented linguistic evidence that suggested not only Christianity, but also Judaism and Islam had ancient roots involving ritual worship of $A$. muscaria.

Although Allegro had fame as an expert on the Dead Sea Scrolls, his hypothesis received little serious attention, but rather was summarily dismissed in what has been alleged to have been a deceitful and repressive cover-up by Gordon Wasson (see Irvin, 2008; also see Brown \& Brown, 2016 and their article below). Wasson's rejection of The Sacred Mushroom \& the Cross was not on the basis of an objective evaluation of the evidence. Rather than engaging Allegro's information and arguments on the origins of Christianity in mushroom cults, Wasson summarily dismissed Allegro's ideas and subjected Allegro's work to ridicule through intellectually questionable behavior (Irvin, 2008). By reference to private correspondence, Irvin reveals that Wasson's dismissal of Allegro's work was not because he read it Wasson apparently confided to others that he did not even read Allegro's book. Instead Wasson took the opinions of a rabbi and a priest and dissuaded further research in this area.

But as we will see below, there is strong evidence for entheogenic cults using psychedelic mushrooms within Christianity. Evidence supporting Allegro's hypothesis of the ancient entheogenic roots of Christianity is found in the repeated appearance of mushroom representations in later Christian art, some with the typical characteristics of A. muscaria, and other depictions resembling local psychedelic species of the Psilocybe and Stropharia genera (see Brown \& Brown, 2016; Hoffman et al., 2002; Ruck, 2017, 2011; Ruck et al., 2001). Allegro (2008) received posthumus support in a rerelease of his book with additional evidence provided by Carl Ruck (also see Brown and Brown's article here).

\section{Psychedelic mushrooms in Catholic art and architecture}

Although many aspects of entheogenic knowledge disappeared from European cultures, this ritual knowledge and messages regarding entheogenic mushrooms remained blatantly displayed - for the initiate - in Christian artifacts, from architectural features such as fungiform door frames to elaborate commissioned art works with mushrooms conspicuously displayed in key areas - such as above the hand of saints. Evidence that such practices persisted through direct transmission is found in the Anthonite healing order and estoeric Christian groups such as the Albigensians and Cathars, and many paintings of Saint Hildegard of Bingen (see Keizer, 2012).

The involvement of $A$. muscaria in the secret rituals of Catholics is indicated by it being well-represented in works of Hildegard of Bingen (1098-1179), a Catholic saint who was also a German Benedictine abbess and an accomplished philosopher, writer, and mystic (Keizer, 2012). The Isenhein altarpiece produced by Matthias Grünewald contains representations of mushrooms, one significantly in the background of outstretched hands of Saint Anthony. The location of the painting within the Abbott of the Anthonites, the followers of St. Anthony (patron of mushroom hunters) who founded a Christian healing order, reflects their secret knowledge and use of A. muscaria. Ruck et al. (2001) note the repetitive allusions to the $A$. muscaria in many significant aspects of the artistic composition. Mushroom caps and stipes subtly surround angels and an A. muscaria mushroom is depicted in the background as if floating in St. Anthony's outstretched hand and pointed finger. Depictions of a raven with the "raven's bread" (A. muscaria) and the stag (the urine of which provides an enhanced psychoactive preparation) present a scene rich with symbolic references to these ancient entheogenic traditions of Eurasia, as well as the hidden traditions of Christianity.

\section{The psychedelic gospels: The secret history of hallucinogens in Christianity}

In the article "Entheogens in Christian Art: Wasson, Allegro and the Psychedelic Gospels," Jerry Brown and Julie Brown provide an in-depth analysis of the presence of entheogenic mushroom images in early and medieval Christian art. They begin with a review of the controversy between avocational ethnomycologist R. Gordon Wasson and philologist John Marco Allegro regarding the presence of psychoactive mushrooms in Christianity particularly the identification of a figure in the 12th century Chapel of Plaincourault in France as a representation of an A. muscaria mushroom. This seminal debate about the role of entheogens in Christianity was then decided in Wasson's favor, who discounted the Amanita interpretation by reference to an opinion of an art historian, who characterized it as a stylized pine tree in private correspondence with Wasson. However, Browns show that in other correspondence, which Wasson did not share, the same authority questioned such identification.

The Browns present a summary of central findings of their book "The psychedelic gospels: The secret history of hallucinogens in Christianity," which presents widespread evidence of entheogens in Christian art found in abbeys, churches, chapels, and cathedrals across Europe and the Middle East. This includes a detailed examination of the evidence for the identification of the Chapel of Plaincourault 
figure as an A. muscaria mushroom, as well as other features of the fresco that identify entheogenic themes. Their fieldwork across Europe and the Middle East provides abundant iconographic evidence of other entheogenic species represented in Christian art, in particular Psilocybe species. They show that time and again, the representations of biblical events have clear depictions of mushrooms that resemble psilocybin-containing species, and that the oversized and central placement of these objects indicate that they are central to the messages of these representations. Their paper provides a review and critique of the various positions taken in the debate regarding the presence of entheogenic mushrooms in Christian art, and asks why Wasson, arguably the leading world figure of the epoch advocating for entheogenic interpretations of the religious past, rejected, until the end of his life, such interpretations of Christian artifacts. The silence of the Catholic Church and art authorities remains a puzzle, unless one endorses a theory of a conspiracy of silence to suppress the entheogenic past of Christianity. Browns call for the establishment of an Interdisciplinary Committee on the Psychedelic Gospels, housed by an academic institution, to examine the evidence for entheogenic mushrooms in Christian art and provide a more satisfactory resolution to what may be the most important knowledge about the origins of this religion.

Brown and Brown's assessment of The Plaincouralt Fresco and its undeniable representation of $A$. muscaria places it as a representation of the Tree of Good and Evil of the Garden of Eden. This situates the A. muscaria sacrament as complex phenomena, simultaneously the forbidden fruit, as well as the means by which humans acquired morality in the knowledge of the difference between good and evil. An entheogen that provides forbidden knowledge also gave the consciousness necessary for morality, as well as Adam and Eve's self-consciousness of their own nakedness.

Whether or not the secret sacrament of early Christianity was originally $A$. muscaria, ergot wheat drinks, or other entheogenic admixtures, the certainty is that A. muscaria practices persisted among esoteric cults, mystery schools, and the Gnostic sects hidden within members of the Catholic Church. A. muscaria traditions also persisted within esoteric societies such as Freemasonry, which incorporated earlier influences of the Knights Templar and other groups (Hoffman et al., 2002). The presence of A. muscaria practices was obscured by the official Church's efforts to stamp them out and by many cult's efforts to hide evidence of use to protect the secrecy of the continuing ritual practices. This leaves questions regarding whether Wasson's opposition to Allegro's ideas was a continuation of the historical repression of entheogenic traditions within Christianity.

\section{The witches' flying ointments}

The survivals of these actual entheogenic-inspired ritual practices also continued well into the second millennium in Europe, occasionally revealed in the practices of those accused of witchcraft, pagan rituals, and various secret societies. Their associations with females are well-noted in the history of the European witchcraft trials, where these female traditions are alleged to use a wide range of powerful psychoactive substances.
In an article "Those Goddamn Ointments: Four Histories," Tom Hatsis documents and analyzes these aspects of entheogenic history of Western Europe that survived into the Renaissance and early modern eras in beliefs regarding "flying ointments." In contrast to the postmodern academic skepticism regarding the actual reality of such ointments, which may attribute such beliefs to the fabrications of fearful religious minds, Hatsis shows us that there is more probably a factual basis for them, albeit in dramatically altered form. While it is true that both theologians' misconstruals and popular fears have fueled many beliefs, such as murdered children and cannibalistic spirit familiars, these constitute an early modern radical reconceptualization of what were prior practices and beliefs. Hatsis similarly contends that the 1970 s popularization of the concept of "flying ointments" by anthropologist Michael Harner (1973) is also a fabrication of that era. Nonetheless, these mistaken construals and fabrications have a likely historical basis in the medieval beliefs regarding what he calls transvection ointments, referring to their alleged ability to make the person fly in some form, or to travel in spirit. Hatsis reviews the evidence that something like this historically documented ointment derived from medieval folk traditions was the basis from which a variety of otherwise inaccurate modern and post-modern beliefs derived. Although the exact composition of such ointments will likely forever remain a mystery, Hatsis concludes "there is every reason to believe that the ointments contained psychoactives," including the various mandrake species of the genus Mandragora, which share the hallucinogen and hypnotic properties derived from their tropane alkaloids. Hatsis proposes that other hallucinogens likely included in these transvection ointments are henbane (Hyoscyamus niger) and belladonna (Atropa belladonna), both with worldwide fame as magical potions. The inclusion of such powerful consciousnessaltering agents in these classic ointments speaks to a shamanic past of these practices, where powerful botanically induced alterations of consciousness were part of ritual healing practices.

Although the exact composition of the witches' brews may remain forever unknown, Rätsch (2005) proposes that there is good evidence that a variety of psychotropic plants were used, including Valeriana officinalis, Mandragora officinarum, H. niger, Papaver spp., A. belladonna, Datura spp., and many others. The use of these powerful psychoactive plants to induce stupor, paralysis, and death-like states was the basis of the extraordinary experiences reported of flying and strange worlds found in many traditions of Europe.

\section{Sacred mushrooms in the Americas}

Ironically, as the Renaissance and Enlightenment finished off the last vestiges of entheogenic spirituality in Europe, it began to bring the same perspectives back into European society through colonial encounters with the foreign other that brought knowledge of shamanism, A. muscaria use, and entheogenic practices into Europe from Siberia and the Americas. The A. muscaria traditions of Eurasia were likely already part of the shamanic cultures of the populations that migrated to the Americas 15,000 years ago or more. 
Although reports of $A$. muscaria traditions are rare in Native American traditions recorded from early contact and ethnographic periods in North America, there is clear evidence of mycolatry in the ethnographic record and mythology. There are also clear representations in the archeological record of Mesoamerica and South America of artifacts representing $A$. muscaria. Representations of various Psilocybe species are also found widely across Mesoamerica and South America. Borhegyi (2010) shows numerous examples of mushrooms in art and artifacts from across central Mexico and Peru, establishing both the antiquity and widespread distribution of an ancient pre-Columbian mushroom cult.

\section{North America}

Evidence for indigenous North American use of $A$. muscaria is reported by several sources (Navet, 1988; Peschel, 1978; Wasson, 1979). Wasson sought and found evidence of contemporary North American A. muscaria ritual among the Ojibway in the writings of Peschel Keewaydinoquay, a woman who was a custodian of her culture's indigenous spiritual traditions. Navet (1988) provides a summary of ethnohistorical sources of information regarding the use of A. muscaria and its role in the origin myth of the Ojibway, where a red and white mushroom buzzes with strange sounds and songs. When Little Brother consumes the biggest of the mushrooms, he is transformed into a mushroom himself. The Big Brother uses drumming, tobacco, and eagle feathers in a ritual that the shamans had recommended. This enabled Big Brother to escape with the little Brother mushroom and transform him back into a human. But something had changed: "Little Brother woke up smiling every morning, the heart happy and a song on his lips" (Navet, 1988, p. 169). Curiously, he cures and resolves misfortunes with the waters that flowed out of his penis, a clear parallel to the Siberian practices of consuming the even more potent urine from one who consumes A. muscaria. Little Brother begins to perform healing rituals based on the powers acquired from the supernatural experience in the land of the mushrooms, providing a mythological verification of a general entheogenic hypothesis of the origin of shamanic-healing practices in the experiences produced by psychedelic mushrooms.

\section{Mesoamerica and Central America}

The prominent mushroom depictions in stone sculptures and ceramics provides clear evidence that psychedelic rituals were central features of ancient Pre-Hispanic American cultures from Mesoamerica down into South America (Torres, 1996, 2006; Torres \& Repke, 2006; Velandia, Galindo, \& Mateus, 2008). The most ancient evidence of sacred mushroom rituals in the Americas may be the representations of $A$. muscaria among the Mayas and Náhuatl in México, represented in ceramics from Mesoamerica and Peru and in stone objects found in Nayarit, Mexico. The Aztec's entheogenic mushroom ceremonies involving the consumption of the sacrament teonanácatl or "God's flesh" were documented by the Spanish chroniclers. Psilocybe species are the predominant candidates and likely involved several species. Guzmán $(2008,2016)$ reviews archeological and botanical evidence that various species of these psilocybin-containing mushrooms were used in sacred rituals in prehistoric México, Mesoamérica, and South America. Borhegyi and Borhegyi-Forrest (2015) analyzed the visual data in Justin Kerr's compilation photographs of ancient Mesoamerican art that illustrate realistic, conventional, and abstract depictions of $A$. muscaria, as well as species with characteristics representative of several Psilocybe species (and possibly Panaeolus species).

The ritual use of entheogenic mushrooms was especially widespread in Mesoamerica and continued into the modern era with more than two dozen psilocybin-containing species used for religious ceremonies in Mexico (Guzmán, 2016; Wasson, 1980). Among the most well-known archeological evidence of fungiforms are the "mushroom stones" discovered during archeological excavations in sites in Guatemala, which Borhegyi examined in the collections of the Guatemalan National Museum. Borhegyi $(1961,1962)$ proposed that these stones were evidence of an ancient cult of mycolatry. The stone effigies carved in the shape of mushrooms that were found in Guatemala establish a high level of organized religious mycolatry in Mesoamerica as early as 600 BCE. But while both Borhegyi and Wasson proposed that the identity of the mushroom stones was $A$. muscaria, Guzmán (2012) proposed the identity of these "mushroom stones" as Psilocybe zapotecorum, based on their robust form and the common appearance of the species in the region.

\section{María Sabina: An ethnographic analogy for ancient Mesoamerican mycolatry}

The Western encounters with the indigenous use of psilocybin mushrooms by Mesoamerican cultures was reported from the cultural distance of the Spanish invaders, whose accounts related by Catholic priests were severely distorted by their ideological views of these practices as involving witchcraft. The violent oppression of these practices led to their virtual extinction in most of Mexico. The surviving practices came to the attention of Western scholars in the early 20th century when anthropologists and ethnobotanists reported their ritual use in Oaxaca Mexico. These investigations among the Mazatec and subsequent publications by Gordon Wasson (Wasson, 1980; Wasson, Cowan, \& Rhodes, 1974) brought international attention to María Sabina, a Mazatec sabia, meaning wise woman. This Mazatec healer and her ritual use of psychedelic mushrooms (Psilocybe caerulescens Murrill and Psilocybe mexicana Heim) and others provides an ethnographic analogy for understanding these ancient traditions (see Estrada, 1977; Munn, 1973). In addition to the mushrooms, María Sabina and other Mazatec healers use other psychoactive plants including Salvia divinorum and local tobacco (Nicotiana rustica L., Solanaceae). These practices (summarized from Schultes \& Winkelman, 1995) provide an ethnographic analogy for understanding the nature of the prehistoric practices.

While María Sabina's practices had obvious Christian influences in her invocations of Jesus, Mary, and Christian saints, her healing activities manifest indigenous traits that are a window to the ancient pre-Columbian Mesoamerican 
use of psychedelic mushrooms in healing rites. María Sabina's training and healing practices reflect the classic features of shamanism found cross-culturally (Winkelman, 1990, 1992). Features of her life and practices involving shamanistic elements are the processes of selection for the vocation, the interactions with mushroom beings or spirits, the experiences of training, the ritual therapeutic activities, and the cosmologies regarding the causes of illness.

María Sabina's grandparents were also "wise ones," her paternal and maternal grandparents practicing as healers. María Sabina began her formation as a shaman at an early age of 6 years, when she ingested mushrooms out of hunger while with her sister attending the cows in the mountains. The experiences that followed gave María Sabina her calling to use mushrooms for healing. These sacraments that she called "saintly children" nourished her during periods of hunger in the forest and gave both sustenance and spiritual inspiration. As expressed in traditions around the world, she experienced the mushrooms speaking to her, manifesting in visions and voices that encouraged her, offered her advice on how to address problems, and eventually gave her the gifts to heal.

This entheogenic origin of her powers, personal development, and healing practices, experienced as direct interaction with the spirit within the mushrooms, is a feature of shamanic experiences that is reported worldwide. The ingestion of the mushrooms provides the spiritual contact and experiences of the training for use of the sacred mushrooms, engaging them as agents that provide wisdom and healing powers. This animistic quality of the experience is exemplified in her personifications of the mushrooms as "saintly children," "little women," "little nuns," "children that sprout," and Christian personages, especially the Virgin Mary and Jesus Christ (Allen, 1997; Estrada, 1977; Wasson et al., 1974).

María Sabina felt that she was born to be a healer, a preordained potential that unfolded as the mushrooms gave her the wisdom necessary for performing the rituals to heal and other powers. These plants were experienced as sentient beings that communicated with her internally in extensive engagements experienced as "language of the mushrooms." These communications from the mushrooms taught the traditions of the wise ones, guiding her professional practice and providing the information needed to diagnose illness and heal. The techniques for using the mushroom are not something the healers learn beforehand, but rather acquire this knowledge directly from the mushrooms when their force acts through the healer's body. The mushrooms speak directly to and through the person, stating the origins of illness and the ritual processes necessary for healing. The healing process is advised by the healer's and patients' visions that reveal the origin of the problem.

The formation of a mushroom healer engages process of self-initiation as the neophyte directly experiences the spirits of the mushrooms in visionary experiences as higher sources of spiritual authority. These entities provided María Sabina access to a Book of Wisdom, spiritual texts that were used to heal with the power derived from the "language of the mushrooms." This power is expressed in the healer's songs that emerge when the mushrooms are consumed and then act through the body of the shaman during the ritual, chanting, singing, speaking, and the directing the healing processes.

The ritual healing is an overnight vigil held in the darkness, generally far from others in a remote house. The ill person is accompanied by their family and other members of the community, and generally remain together overnight. The participants must comply with a number of restrictions, avoiding sexual behavior and alcohol consumption for 4 days before and after the ceremony and fasting from breakfast on the day of the ritual.

The use of mushrooms is necessary for the healer, and may also be ingested by the patients if the healer decides it is necessary. The mushrooms are normally eaten raw, often accompanied by a cup of cacao. The power of the healing ceremony is also produced by the healer's singing and chanting, combined with whistling, humming, and ventriloquistic effects. The healer dances and chants during much of the night, often breaking into words that convey the healing powers of the mushrooms. Munn (1973) characterized the sacred language of the mushrooms as a "poetic art" of words and sounds that are used as tools to elicit emotions and catharsis. María Sabina's diverse use of sounds, not only in singing and chanting, but other monotone rhythmic utterances, also functions as procedures for altering consciousness. The healing done with the mushrooms involves such traditional shamanistic practices as addressing the loss of the soul or spirit of the person, resolving spirit afflictions, providing exorcisms, and removing hexes by sorcerers and witches. The veladas were also used for a physical illness and to resolve disputes. The healer may address the actions of evil spirits, block hexes, or the consequence being enchanted by evil spirits or sorcerers. The healing veladas are normally held to seek a remedy to a persistent health problem, but may be used for acquiring solutions to other problems. The velada is typically focused on the cure illness or to determine the possibility of recovery from some disease and the treatments necessary. The mushrooms are also used in divination to locate lost animals and discover the situation of distant family members.

\section{Costa Rica's entheogenic prehistory}

In their article "Ritual consumption of psychedelic fungi and plants in ancestral Costa Rica," José Manuel Rodríguez Arce and Marco Antonio Arce Cerdas examine artifacts that document the use of psychedelics in pre-Columbian societies that inhabited the current Costa Rican territory. They examine the cultural and social significance of this activity through integration of historical, ethnographic, archeological, and paleobotanical findings. Psychoactive plants of the region included tobacco (Nicotiana spp.), cacao (Theobroma cacao), morning glory (Turbina corymbosa, Ipomoea tricolor, and I. carnata), fly agaric (A. muscaria), cohoba (Anadenanthera peregrina), and various psilocybin mushroom species (e.g., Psilocybe aztecorum and $P$. caerulescens). The 46 artifacts from the Museums of the Central Bank of Costa Rica and the National Museum of Costa Rica reveal the centrality of supernatural ritual practice linked to psychedelics. These aspects of the archeological record together with other data permit a nuanced examination of their use of 
psychoactive substances. Ethnographic analogies suggest these substances were instruments to attain esoteric knowledge that was central to healing practices and a source of social power. Archeological evidence that psychedelic drug use was most frequent in the record during the period from $300 \mathrm{BCE}$ to $300 \mathrm{CE}$ suggest that psychedelics and their effects were instrumental in the emergence of sociopolitical formations in ancient Costa Rica. This significance is attested to by the placement of a mushroom-shaped ceramic statue in an elite burial along with sumptuary symbolic objects (carved jade effigies), along with snuff inhalers (rather than pipes). These inhalers appear to have been employed as insignia of political and ceremonial rank, as attested by the presence of worn down orifices for suspending them as pendants. Access to entheogenic ritual knowledge was part of the source of power of high-ranking leaders and may have played a role decision-making and coordination of tasks during a period of sociopolitical complexification.

\section{South America}

Evidence of ancient sacred mushroom practices in Peru is found in iconographic depictions that document the ritual use of sacred mushrooms on stones, ceramic vessels, and in metal work. Trutmann (2012) presents photographs from diverse sources that show these mushrooms representations in Moche ceramic artifacts (dated between $100 \mathrm{BCE}$ and 800 AD) that have realistic representations of Psilocybe species and A. muscaria. Trutmann (2012) reviews archeological evidence of sacred mushroom use in prehistoric Peru in the Cupisnique, Paracas, Moche, Chimú and Pukará cultures, as well as the mushroom stones of Chucuito (see Figures 8 and 9 for photographs). Trutmann presents these various stone mushrooms as evidence of their ancient ritual use among a number of areas in coastal and highland Peru dating from as early as 1200 BCE. These mycolatry practices continued until the European conquest, as evidenced in documents from the end of the 17th century. Schultes (1966) summarized evidence that the Yurimagua culture of the Peruvian Amazon employed an inebriating beverage based on a tree fungus that was likely Psilocybe

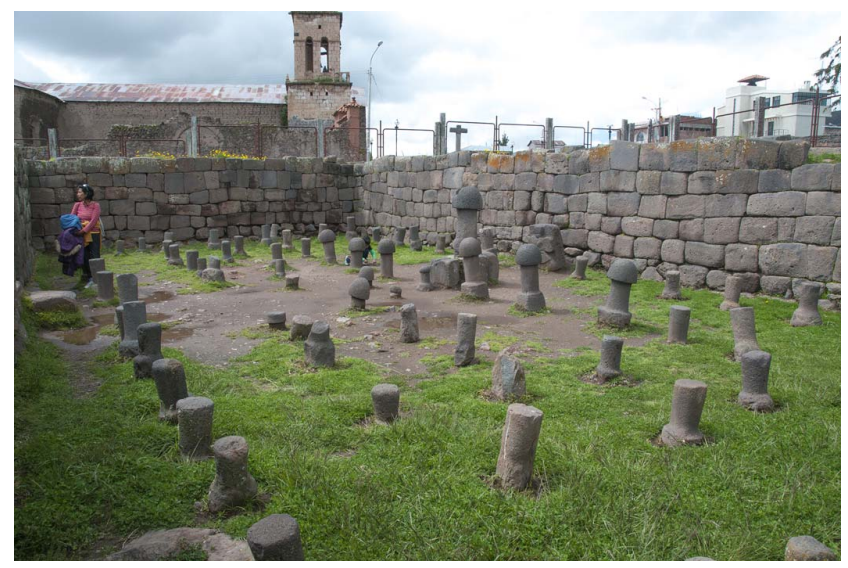

Figure 8. An image from Inka Uyo, showing a collection of ordinary roof bearing stones together with mushroom-shaped stones collected from around Chucuito Peru (photo credit: Peter Trutmann; used with permission)

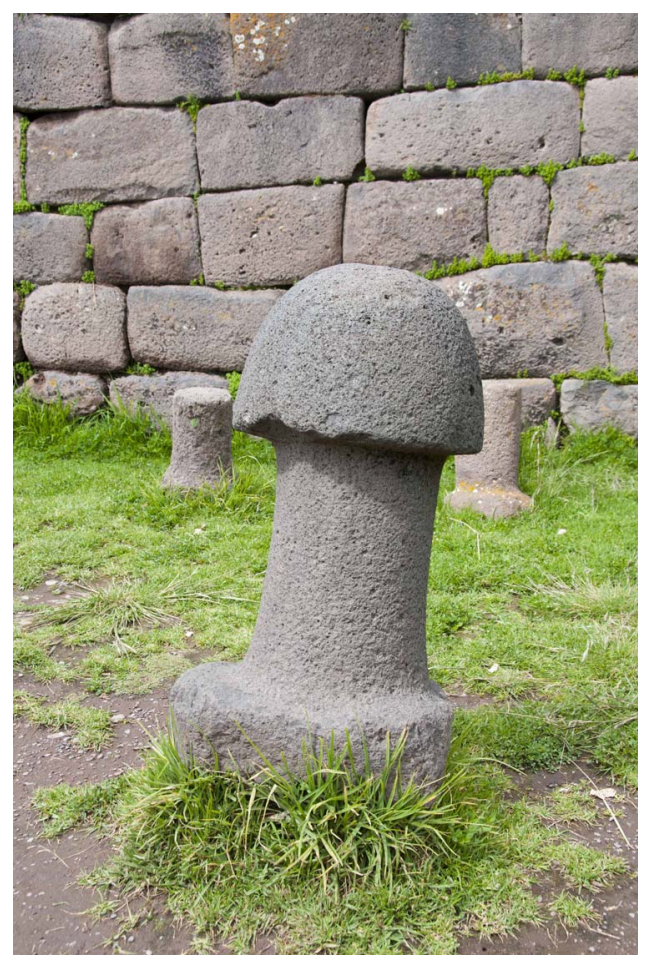

Figure 9. A mushroom-shaped stone from Chucuito, Peru (photo credit: Peter Trutmann; used with permission)

yungensis, which was also used ritually in Bolivia and southern Mexico.

These mushroom representations provide evidence of not only the use of various Psilocybe species, but also the famous $A$. muscaria mushroom, easily recognized because of its red and white coloration. This later species, represented in ancient ceramics but not documented in contemporary ethnobotany of Peru, suggests that long distance trade in these sacred items and the ancient Peruvian practice of borrowing of sacred plants from other cultural traditions. Analyses of artistic representations by Velandia et al. (2008) illustrate some of the frequent motifs of South America iconography in relationship to fungiforms and conventional representations of mushrooms, making the argument that abstract mushroom representations are far more widespread than apparent.

\section{Ancient psychoactive plant use in the North Andes}

In his article "The Use of Psychoactive Plants and Fungi by Ancient Indigenous Populations of the North Andes, ” Manuel Torres presents evidence of the widespread ceremonial use of entheogenic plants in the ancient cultures of South America. He reviews evidence that the use of entheogenic plants permeated these cultures as a core feature of shamanic religious practices. The importance of these entheogenic substances was expressed in a complex iconographic systems revealed in a variety of media, most of which survived in stone sculptures and gold work. These include the San Pedro cactus

Echinopsis sp. (synonym: Trichocereus sp.) and psychoactive snuffs from Anadenanthera colubrinai practices are still attested to in South American cultures today. The fungiform 
representations in the Darién pendants have been identified as psychedelic mushrooms by several authorities, consistent with the entheogenic themes found in burial artifacts. Torres provides iconographic analyses of ceremonial paraphernalia to show how they reveal the central role of entheogens in the religious practices of the ancient cultures of this region.

However, with rare exceptions outside of Mesoamerica, these entheogenic mushroom rituals were not reported in the historical or near-contemporary ethnographic documents produced by the Western world. The exact nature of these ancient entheogenic practices was lost due a variety of factors, perhaps the most important of these being the extremely destructive influences of the prohibition of consumption and teaching about these substances issued by Catholic Inquisition. This repression upon threat of punishment with death by torture that persisted well into the colonial period in the Americas assured the loss of the knowledge regarding these practices during the subsequent formation of mestizo cultures through acculturation. Furthermore, this repression contributed to the production of mycophobic attitudes in the mestizo cultures, further contributing to extinction of knowledge regarding entheogenic ritual practices. Even today "Christian" people of indigenous cultures may set out to kill their more "primitive" neighbors who harbor and engage in these ancient shamanic practices.

\section{CONCLUSIONS: THE MODERN LOSS AND ETERNAL RETURN OF ENTHEOGENIC SPIRITUALITY}

Interdisciplinary evidence regarding the entheogenic use of mushrooms provides perspectives for interpreting findings from investigations by archeologists and ethnobotanists. What this entheomycological research has revealed is that religious activities focused on the entheogenic use of psychedelic mushrooms were present in all of the major geographical regions of the world. These widespread practices indicate that use of entheogenic mushrooms is a universal religious heritage of humanity. This simple fact should lead to unequivocal support for an entheogenic paradigm, specifically mycolatry, when iconographic evidence of fungiforms is found in the archeological record. Arguments for culinary or other ethnobotanical representations should be required to provide extraordinarily robust evidence to counter what is arguably a virtual universal of human cultures - evidence of beliefs and practices related to the entheogenic use of psychoactive mushrooms.

The continuity of these entheogenic mushroom traditions from prehistoric shamanic traditions into historical cultures is attested to the articles in this special issue. The entheogenic encounters that inspired the evolution of shamanism continued in the practices of historical and contemporary religions - Hinduism, Buddhism, Jainism, Judaism, Islam, Christianity, and others. While the coverage provided in this introduction and the following articles is not a comprehensive review of this evidence, it points to the widespread evidence of psychedelic mushrooms and other entheogens in the early formation of the major world religions. The shamanic impulse that gave rise to worldwide entheogenic practices was, however, more hidden in these traditions of complex societies, where the knowledge regarding use of these substances was now an exclusive practice of a priestly class. This hiding of secret knowledge regarding entheogenic use contributed to the general loss of knowledge about mushroom-induced transformations of consciousness that give rise to religious traditions.

Entheogens, especially mushrooms of the Amanita and Psilocybe genera, have inspired countless spiritual encounters and traditions in the past. But are entheogenic-inspired religions just a phenomena of the remote past, a relic of a previous era and human mentality when humans were more susceptible to the chemically inspired entheogenic encounters? Or are these entheogenic potentials still part of the modern ecopsychology of humanity. Our final article here gives an emphatic "Yes!"

\section{A modern entheogenic-origin religion: Mormonism}

In the article "The Entheogenic Origins of Mormonism," Robert Beckstead and his co-authors Bryce Blankenagel, Cody Noconi, and Michael Winkelman present evidence regarding the entheogenic origins of the Church of Latter Day Saints, known as Mormonism. This modern worldwide religion has its roots in the early 19th century American Midwest with Joseph Smith Jr., the founder who rapidly gathered thousands of recruits to Mormonism with the compelling power of visionary experiences. The authors argue that this was due to the convincing power of entheogenic-induced experiences. The family of Smith shows evidence of a history of entheogenic knowledge that produced his revelatory experiences and that entheogens were incorporated into the early Mormon Church in sacraments, anointing, and temple rituals. The 19th century historical data related to the rise of Mormonism and events in Joseph Smith's life and the experiences of early Mormon converts suggest the ritual use of entheogenic material was explored, systematized, and modified by Joseph Smith Jr. in the founding period of Mormonism. The unusual features of visionary and spiritual experiences reported during early periods of Mormonism mimic the anti-cholinergic syndrome produced by Datura stramonium. The neurophysiological and phenomenological effects of various entheogenic plants explain the unusual symptomatology reported in newspapers of the time, as well as ego dissolution, visionary experiences, and mood-enhancing sequelae experienced by Mormons. Mormonism is a very important example of entheogen-inspired religions, showing that they are not just a thing of our ancient past, but also part of recent history. Mormonism shows the power of a few early entheogenic experiences to inspire the formation of a religious organization that can persist long after its founders and their entheogenic stimuli have faded from the scene.

\section{Entheogens as a universal religious heritage}

Our various contributions here on the entheogenic elements of religions of the past - and their descendants in the present provide ample data for assertions about a common worldwide basis of religious experiences in psychedelics and their influences in the formation of humanity's religions. The roots 
of entheogenic religions in shamanistic practices are not just a relic of the past, but also a part of the present, as exemplified in the many contemporary ayahuasca practices and churches. Perhaps, entheogenic religion is here to stay. It is after all part of our evolution and nature. One can hope that this nascent stage of reemergence will move beyond this into an entheogenic revival, a global movement of spiritual acceptance across traditions that is worthy of the sacred mushrooms' long history.

Shortly before his death, Wasson recanted on his rejection of the Allegro's hypothesis regarding the entheogenic origins of Christianity, proclaiming in his final book, Persephone's Quest (Wasson, Kramrisch, Ott, \& Ruck, 1986): "I once said there was no mushroom in the Bible. I was wrong. It plays a hidden role (that is, hidden from us until now) and a major one, in what is the best-known episode of the Old Testament, the Garden of Eden story and what happened to Adam and Eve.... I hold that the fruit of the Tree of Knowledge of Good and Evil was Soma... was the Amanita muscaria."

As proclaimed in the subtitle of the book - Entheogens and the Origins of Religion - the primordial origins of religious thought and experience are found in the neurophenomenology of psychedelic mushrooms and other entheogenic plants. Unfortunately, Wasson did not support Allegro's hypothesis in that crucial time when he could have changed the course of entheogenic and Christian studies.

"Jesus said to them: Amen, amen I say unto you: Except you eat the flesh of the Son of man, and drink his blood, you shall not have life in you."

If this refers to A. muscaria and psilocybin-containing mushroom species, the real Christian Pentecost may still await humanity. Spiritual experiences of many religious traditions apparently originated in the effects of $A$. muscaria and Psilocybe species. Our religions - Judaism, Buddhism, Hinduism, Christianity, Islam, and others, including Mormonism - have ancient roots in entheogenic experiences produced by these fungi, as well as numerous sacred plants. Humanity can recover their true spiritual roots through the ritual engagement with these sacraments. And if we do so we will become better people from the experiences. That is another paper, but the evidence is there that these substances make us more egoless, other-oriented, altruistic, compassionate, open, tolerant, friendly, and less fearful, anxious, depressed, etc. - effects that undoubtedly benefited us in the past and can do so in the future.

Acknowledgements: The author received no support for this work and is responsible for all aspects of this article.

Conflict of interest: The author has no conflicts of interest nor any financial incentive for the ideas expressed here.

\section{REFERENCES}

Akers, B., Ruiz, J., Piper, A., \& Ruck, C. (2011). A prehistoric mural in Spain depicting neurotropic psilocybe mushrooms? Economic Botany, 65(2), 121-128. doi:10.1007/s12231-011-9152-5

Allegro, J. (1970). The sacred mushroom and the cross. New York, NY: Doubleday.
Allegro, J. (2008). The sacred mushroom and the cross. Grand Terrace, CA: Gnostic Media.

Allen, J. W. (1997, October). Teonanácatl: Ancient and contemporary shamanic mushroom names of Mesoamerica and other regions of the World. Ethnomycological journals: Sacred mushroom studies (Vol. III, pp. 1-47). Seattle, Washington: Psilly Publications and Raver Books.

Berlant, S. (2005). The entheomycological origin of Egyptian crowns and the esoteric underpinnings of Egyptian religion. Journal of Ethnopharmacology, 102(2), 275-288. doi:10.1016/j.jep.2005.07.028

Bogoraz, V. (1909). The Chukchee. Social organization. The Jesup North Pacific Expedition 7, Social organization (Vol. 11, pp. 537-733). New York: American Museum of Natural History.

Borhegyi, S. (1961). Miniature mushroom stones from Guatemala. American Antiquity, 26(4), 498-504. doi:10.2307/278737

Borhegyi, S. (1962). The enigmatic mushroom stones of meso-America. New Orleans, LA: Middle American research Institute, Tulane University.

Borhegyi, C. (2010). Mushroom symbolism in pre-Columbian art. Retrieved from http://www.mushroomstone.com

Borhegyi, C., \& Borhegyi-Forrest, S. (2015). Mushroom intoxication in meso-America. In P. Wexler (Ed.), History of toxicology and environmental health. Amsterdam, The Netherlands: Academic Press.

Brown, J., \& Brown, J. (2016). The psychedelic gospels: The secret history of hallucinogens in Christianity. Rochester, VT: Park Street Press.

Crowley, M. (2015). Umbrellas, wheels, and bumps on the head: A proposed solution to the Ușnīṣa mystery. Time and Mind, 8(2), 191-218. doi:10.1080/1751696X.2015.1026028

Dannaway, F. (2009). Thunder among the pines: Defining a panAsian soma. Journal of Psychoactive Drugs, 41(1), 67-84. doi:10.1080/02791072.2009.10400676

De Smet, P. (1996). Some ethnopharmacological notes on African hallucinogens. Journal of Ethnopharmacology, 50(3), 141-146. doi:10.1016/0378-8741(95)01337-7

Devlet, E., \& Devlet, M. (2002). Siberian shamanistic rock art. In A. Rozwadowski \& M. Kosko (Eds.), Spirits and stones shamanism and rock art in Central Asia and Siberia (pp. 120-136). Poznan, Poland: Instytut Wschodni Uam.

Dobkin de Rios, M. (1984). Hallucinogens: Cross cultural perspectives. Albuquerque, NM: University of New Mexico.

Donald, M. (1991). Origins of the modern mind. Cambridge, MA: Harvard University Press.

Dunbar, R. (2014). Human evolution: A pelican introduction [Kindle iOS version]. Retrieved from Amazon.com

Estrada, A. (1977). Vida de María Sabina, la sabia de los hongos [The life of Maaria Sabina, Wise woman of the mushrooms]. México: Siglo XXI.

Feeney, K. (2010). Revisiting Wasson's soma: Exploring the effects of preparation on the chemistry of Amanita muscaria. Journal of Psychoactive Drugs, 42(4), 499-506, doi:10.1080/ 02791072.2010 .10400712

Fitzpatrick, S. (Ed.). (2018). Ancient psychoactive substances. Gainesville, FL: University Press of Florida.

Fitzpatrick, S., \& Merlin, M. (2018). Introduction.Drugs from a deep time perspective. In S. Fitzpatrick (Ed.), Ancient psychoactive substances (pp. 1-19). Gainesville, FL: University Press of Florida. 
Guerra-Doce, E. (2006). Las drogas en la prehistoria: Evidencias arqueológicas del consume de sustancias psicoactivas en Europa [Drugs in prehistory: Archaeological evidence for consumption of psychoactive substances in Europe]. Barcelona, Spain: Bellaterra.

Guerra-Doce, E. (2015). Psychoactive substances in prehistoric times: Examining the archaeological evidence. Time \& Mind, 8(1), 91-112. doi:10.1080/1751696X.2014.993244

Guzmán, G. (2005). Species diversity of the genus psilocybe (Basidiomycotina, Agaricales, Strophariaceae) in the world mycobiota, with special attention to hallucinogenic properties. International Journal of Medicinal Mushrooms, 7(1), 305-332. doi:10.1615/IntJMedMushr.v7.i12.280

Guzmán, G. (2008). Hallucinogenic mushrooms in Mexico: An overview. Economic Botany, 62(3), 404-412. doi:10.1007/ s12231-008-9033-8

Guzmán, G. (2009). The hallucinogenic mushrooms: Diversity, traditions, use and abuse with special reference to the genus psilocybe. In J. K. Misra \& S. K. Deshmukh (Eds.), Fungi from different environments (pp. 256-277). Enfield, UK/Jersey, NJ/ Plymouth, UK: Science Publishers.

Guzmán, G. (2012). New taxonomical and ethnomycological observations on psilocybe s. s. (fungi, basidiomycota, agaricomycetidae, agaricales, strophariaceae) from Mexico, Africa and Spain. Acta Botánica Mexicana, 100(100), 79-106. doi:10.21829/abm100.2012.32

Guzmán, G. (2016). Las relaciones de los hongos sagrados con el hombre a través del tiempo [The relations across time of sacred mushrooms with humans]. Anales de Antropología, 50(1), 134-147. doi:10.1016/j.antro.2015.10.005

Guzmán, G., Allen, J., \& Gartz, J. (1998). A world wide geographical distribution of the neurotropic fungi, an analysis and discussion. Annali dei Museo civico, Rovereto, 14, 189-280.

Hajicek-Dobberstein, S. (1995). Soma, siddhas and alchemical enlightenment: Psychedelic mushrooms in Buddhist tradition. Journal of Ethnopharmacology, 48(2), 99-118. doi:10.1016/ 0378-8741(95)01292-L

Harner, M. (1973). The role of hallucinogenic plants in European witchcraft. In M. Harner (Ed.), Hallucinogens and Shamanism (pp. 125-150). New York, NY: Oxford University Press.

Hillman, D. (2014). Sex, snake venom, and cult: The use of compound psychotropics by Greco-Roman priestesses. In J. Rush (Ed.), Entheogens and the development of culture (pp. 113-127). Berkeley, CA: North Atlantic Books.

Hoffman, M., Ruck, C., \& Staples, B. (2002). The entheogenic Eucharist of Mithras. Entheos, 2(1), 13-46.

Hollmann, J. (1993). Preliminary report on the Koebee rock paintings of Western Cape Province, South Africa. South Africa Archaeological Bulletin, 48(157), 16-25. doi:10.2307/3888872

Hoppál, M. (2013). Shamans and symbols prehistory of semiotics in rock art. Budapest, Hungary: International Society for Shamanistic Research.

Irvin, J. (2008). The holy mushroom: Evidence of mushrooms in Judea-Christianity. A critical re-evaluation of the schism between John M. Allegro and R. Gordon Wasson over the theory on the entheogenic origins of Christianity presented in The Sacred Mushroom and the Cross. Grand Terrace, CA: Gnostic Media.

Kaplan, R. W. (1975). The sacred mushroom in Scandinavia. Man, 10(1), 72-79. doi:10.2307/2801183

Keizer, G. (2012). Hildegard of Bingen: Unveiling the secrets of a medieval high priestess and visionary. In J. A. Rush (Ed.),
Entheogens and the development of culture (pp. 85-210). Berkeley, CA: North Atlantic Books.

Lajoux, J. (1964). Le meraviglie del Tassili [The wonders of Tassili]. Bergamo, Italy: Instituta Arti Grafiche.

Lhote, H. (1968). Données récentes sur les gravures et les peintures rupestres du Sahara [Recent data on the engravings and rock paintings of the Sahara]. In E. Ripall Perellá (Ed.), Simposio de Arte Rupestre. Barcelona, Spain.

Lhote, H. (1973). A la découverte des fresques du Tassili [The discovery of the frescoes of Tassili]. Paris, France: Arthaud.

Molodin, V., \& Cheremisin, V. (1999). Petroglyphes de l'Age du bronze du plateau d'Ukok: A propos des representations de personages avec une coiffure fongiform [Bronze Age petroglyphs of the Ukok Plateau: About representations of personages with a fungiform hairstyle]. Arts Asiatiques, 54(1), 148-152. doi:10.3406/arasi.1999.1440

Morgan, A. (1995). Toads and toadstools: The natural history, mythology, and cultural oddities of this strange association. Berkeley, CA: Celestial Arts.

Mori, F. (1974). The earliest Saharian rock-engravings. Antiquity, 48(190), 87-92. doi:10.1017/S0003598X00054314

Munn, H. (1973). The mushrooms of language. In M. Harner (Ed.), Hallucinogens and shamanism (pp. 86-122). New York, NY: Oxford.

Navet, É. (1988). Les ojibway et l'amanite tue-mouche (amanita muscaria). Pour une ethnomycologie des Indiens d'Amérique du nord [The Ojibway and the fly agaric (Amanita muscaria). For an ethnomycology of North American Indians]. Journal de la Société des Américanistes, 74, 163-180. doi:10.3406/ jsa.1988.1334

Peschel, K. (1978). Puhpohwee for the people: A narrative account of some uses of fungi among the Ahnishinaabeg. Cambridge, MA: Botanical Museum of Harvard University.

Pregenzer, J., Alberts, G., Bock, J., Slightom, J., \& Im, W. (1997). Characterization of ligand binding properties of the 5-HT1D receptors cloned from chimpanzee, gorilla and rhesus monkey in comparison with those from the human and guinea pig receptors. Neuroscience Letters, 235(3), 117-120. doi:10.1016/S0304-3940(97)00728-3

Rätsch, C. (2005). The encyclopedia of psychoactive plants: Ethnopharmacology and its applications. Rochester, NY: Park Street Press.

Reay, M. (1960). Mushroom madness in the New Guinea highlands. Oceania, 31(2), 137-1399. doi:10.1002/j.1834-4461.1960. tb00746.x

Rossano, M. (2007). Did meditating make us human? Cambridge Archaeological Journal, 17(1), 47-58. doi:10.1017/S0959774 307000054

Rossano, M. (2009). Ritual behavior and the origins of modern cognition. Cambridge Archaeological Journal, 19(2), 243-256. doi:10.1017/s0959774309000298

Rossano, M. (2011). Setting our own terms: How we used ritual to become human. In H. Walach, S. Schmidt, \& W. Jonas (Eds.), Neuroscience, consciousness and spirituality (pp. 39-55). Berlin, Germany: Springer.

Rozwadowski, A., \& Kosko, M. (2002). Spirits and stones shamanism and rock art in central Asia and Siberia. Poznan, Poland: Instytut Wschodni Uam.

Ruck, C. (2006). Sacred mushrooms: Secrets of Eleusis. Berkely, CA: Ronin Publishing. 
Ruck, C. (2014). Shamanic induction of altered states for spiritual inspiration. In J. Harold Ellens (Ed.), Seeking the sacred with psychoactive substances: Chemical paths to spirituality and to God (Vol. 2, pp. 45-54). Santa Barbara, CA: Praeger/ ABC-CLIO.

Ruck, C. (Ed.). (2017). Dionysus in thrace: Ancient entheogenic themes in the mythology and archaeology of Northern Greece, Bulgaria, and Turkey. Berkeley, CA: Regent Press.

Ruck, C., Hoffman, M., \& González-Celdrán, J. (2014). Mushrooms, myth, and Mithras: The drug cult that civilized Europe. San Francisco, CA: City Lights Books.

Ruck, C., Staples, B., \& Heinrich, C. (Eds.). (2001). The apples of Apollo: Pagan and Christian mysteries of the Eucharist. Durham, NC: Carolina Academic Press.

Rush, J. (2011). The mushroom in Christian art: The identity of Jesus in the development of Christianity. Berkeley, CA: North Atlantic Books.

Saar, M. (1991). Ethnomycological data from Siberia and northeast Asia on the effect of Amanita muscaria. Journal of Ethnopharmacology, 31(2), 157-1733. doi:10.1016/03788741(91)90002-U

Samorini, G. (1989). Etnomicologia dell'arte rupestre sahariana (Periodo delle Teste Rotonde) [Ethnomycology of Saharan rock art (Round Head Period)]. Bollettino Camuno Notizie, 6(2), 18-22.

Samorini, G. (1990). Sciamanisma, funghi psicotropi e stati alterati di coscienza: Un rapporto da chiarire [Shamanism, psychotropic fungi and altered states of consciousness: A report to be clarified]. Bollettino Camuno Studi Preistorici, 25/26, 147-150.

Samorini, G. (1992). The oldest representations of hallucinogenic mushrooms in the world (Sahara desert, 9000-7000 BP). Integration, 2(3), 69-78.

Samorini, G. (1998). The pharsalus bas-relief and the Eleusinian mysteries. The Entheogen Review, 7(2), 60-63.

Samorini, G., (2012). Mushroom effigies in world archaeology: From rock art to mushroom-stones. In D. Spasova (Ed.), Proceedings of the Conference "The Stone Mushrooms of Thrace” (pp. 16-42). Alexandroupoli, Greece: Greek Open University.

Schultes, R. (1966). The search for new natural hallucinogens. Lloydia, 29, 297.

Schultes, R., Hofmann, A., \& Rätsch, C. (1992). Plants of the gods: Their sacred, healing and hallucinogenic powers. Rochester, VT: Healing Arts Press.

Schultes, R., \& Winkelman, M. J. (1995). The principal American Hallucinogenic plants and their bioactive and therapeutic properties. In M. J. Winkelman \& W. Andritzky (Eds.), Sacred plants, consciousness and healing: Cross-cultural and interdisciplinary perspectives. Yearbook of cross-cultural medicine and psychotherapy (Vol. 5, pp. 205-240). Berlin, Germany: Verlag.

Schurr, T. (1995). Aboriginal Siberian use of amanita muscaria in shamanistic practices: Neuropharmacological effects of fungal alkaloids ingested during trance induction, and the cultural patterning of visionary experience. Curare, 18(1), $31-65$.

Sobiecki, J. (2017). Psychoactive initiation plant medicines: Their role in the healing and learning process of South African and Upper Amazonian traditional healers. In D. McKenna (Ed.), Ethnopharmacological search for psychoactive drugs (pp. 175-180). London, UK: Synergetic Press, Ltd.
Stamets, P. (1996). Psilocybin mushrooms of the world. Berkeley, CA: Ten Speed Press.

Stijve, T. (1997). Hallucinogenic bolets in China? Eleusis, 7, 33.

Sullivan, R., \& Hagen, E. (2002). Psychotrophic substanceseeking: Evolutionary pathology or adaptation? Addiction, 97(4), 389-400. doi:10.1046/j.1360-0443.2002.00024.x

Sullivan, R., Hagen, E., \& Hammerstein, P. (2008). Revealing the paradox of drug reward in human evolution. Proceedings of the Royal Society B, 275(1640), 1231-1241. doi:10.1098/rspb. 2007.1673

Torres, C. (1996). Archaeological evidence for the antiquity of psychoactive plant use in the Central Andes. Annali dei Museo civico, Rovereto, 11, 291-326.

Torres, C. (2006). Los colgantes Darien. Evidencia para el uso de hongos visionarios en los Andes Septentrionales? [The Darien pendants. Evidence for the use of visionary mushrooms in the Northern Andes] Revista Cultura y Droga, 11, 47-62.

Torres, C., \& Repke, D. (2006). Anadenanthera. Visionary plant of ancient South America. New York, NY: Haworth Press.

Trutmann, P. (2012). The forgotten mushrooms of ancient Peru. Global Mountain Action. Fungi and Mountains Publication Series: No 1. Retrieved from https://www.researchgate.net/ publication/233853675_THE_FORGOTTEN_MUSHROOMS_ OF_ANCIENT_PERU

Velandia, C., Galindo, L., \& Mateus, K. (2008). Micolatría en la iconografía prehispánica de América del Sur [Mycolatry in the pre-Hispanic iconography of South America]. International Journal of South American Archaeology, 3, 1-23.

Wasson, G. (1972). Soma the divine mushroom of immortality. New York, NY: Harcourt Brace Jovanovich.

Wasson, G. (1979). Traditional use in North America of Amanita muscaria for divinatory purposes. Journal of Psychedelic Drugs, 11(1-2), 25-28. doi:10.1080/02791072.1979. 10472088

Wasson, G. (1980). The wonderous mushroom: Mycolatry in Mesoamerica. New York, NY: McGraw Hill.

Wasson, G., Cowan, G., \& Rhodes, F. W. (1974). Maria Sabina and her mushroom velada. New York, NY: Harcourt Brace Jovanovich.

Wasson, G., Hoffman, A., \& Ruck, C. (1978). The road to Eleusis: Unveiling the secret of the mysteries. New York, NY: Harcourt Brace Jovanovich.

Wasson, G., Kramrisch, S., Ott, J., \& Ruck, C. (1986). Persephone's quest entheogens and the origins of religion. New Haven, CT: Yale University Press.

Winkelman, M. (1990). Shaman and other "magico-religious" healers: A cross-cultural study of their origins, nature and social transformations. Ethos, 18(3), 308-352. doi:10.1525/ eth.1990.18.3.02a00040

Winkelman, M. (1992). Shamans, priests, and witches. A crosscultural study of magico-religious practitioners (Anthropological Research Papers \#44). Tempe, AZ: Arizona State University.

Winkelman, M. (2002). Shamanism and cognitive evolution. Cambridge Archaeological Journal, 12(1), 71-101. doi:10.1017/ S0959774302000045

Winkelman, M. J. (2007). Shamanic guidelines for psychedelic medicines. In M. J. Winkelman \& T. Roberts (Eds.), Psychedelic medicine: New evidence for hallucinogenic substances as treatments (Vol. 2, pp. 143-167). Westport, CT: Praeger/ Greenwood Publishers. 
Winkelman, M. J. (2009). Shamanism and the origins of spirituality and ritual healing. Journal for the Study of Religion, Nature and Culture, 3(4), 458-489. doi:10.1558/jsrnc.v3i4.458

Winkelman, M. J. (2010a). Shamanism: A biopsychosocial paradigm of consciousness and healing (2nd ed.). Santa Barbara, CA: ABC-CLIO.

Winkelman, M. J. (2010b). The shamanic paradigm: Evidence from ethnology, neuropsychology and ethology. Time and Mind: The Journal of Archaeology, Consciousness and Culture, 3(2), 159-181. doi:10.2752/175169610X12632 240392758

Winkelman, M. J. (2010c). Evolutionary origins of ritual. In A. Michaels (Ed.), Body, performance, agency, and experience (pp. 331-349). Wiesbaden, Germany: Harrassowitz Verlag.

Winkelman, M. J. (2011). A paradigm for understanding altered consciousness: The integrative mode of consciousness. In E. Cardeña \& M. J. Winkelman (Eds.), Altering consciousness multidisciplinary perspectives: Volume 1. History, culture and the humanities (pp. 23-44). Santa Barbara, CA: Preager ABC-CLIO.

Winkelman, M. J. (2013). Shamanism and psychedelics: A biogenetic structuralist paradigm of ecopsychology. European Journal of Ecopsychology, 4, 90-115.
Winkelman, M. J. (2014a). Shamanic consciousness and human evolution. In J. H. Ellens (Ed.), Seeking the sacred with psychoactive substances: Chemical paths to spirituality and god (Vol. 1, pp. 129-155). Santa Barbara, CA: Praeger/ ABC-CLIO.

Winkelman, M. J. (2014b). Evolutionary views of entheogenic consciousness. In J. H. Ellens (Ed.), Seeking the sacred with psychoactive substances: Chemical paths to spirituality and god (Vol. 1, pp. 341-364). Santa Barbara, CA: Praeger/ABC-CLIO.

Winkelman, M. J. (2015). Shamanism as a biogenetic structural paradigm for humans' evolved social psychology. Psychology of Religion and Spirituality, 7(4), 267-277. doi:10.1037/rel0000034

Winkelman, M. J. (2017a). Mechanisms of psychedelic visionary experiences: Hypotheses from evolutionary psychology. Frontiers in Neuroscience, 11, article 539. doi:10.3389/fnins.2017.00539

Winkelman, M. J. (2017b). Shamanism and the brain. In N. K. Clements (Ed.), Religion: Mental religion. MacMillan Interdisciplinary handbooks (pp. 355-372). Farmington Hills, MI: MacMillan Publishers.

Winkelman, M. J. (2018). An ontology of psychedelic entity experiences in evolutionary psychology and neurophenomenology. Journal of Psychedelic Studies, 2(1), 5-23. doi:10.1556/2054.2018.002 